\title{
DISCRIMINACIÓN Y MANIFESTACIONES RELIGIOSAS EN EL DEPORTE PROFESIONAL
}

\author{
Irene María BRIONES MARTÍNEZ \\ Catedrática de Derecho Eclesiástico del Estado \\ Departamento de Derecho Internacional, \\ Eclesiástico y Filosofía del Derecho. \\ Facultad de Derecho. \\ Universidad Complutense de Madrid \\ iremar@der.ucm.es
}

\begin{abstract}
RESUMEN
Las manifestaciones religiosas de las personas, deportistas o no, forman parte del ejercicio de la libertad religiosa, que como raíz de las libertades implica a la conciencia y a la libertad de expresión. En el caso de los deportistas profesionales, nos encontramos con probibiciones que defienden un lugar aséptico de ideologías y creencias para crear un espacio de identidad compuesto de valores comunes que contribuyan a la paz y al desarrollo. El conflicto es evidente, las libertades individuales de personas con una identidad propia frente a un mundo aséptico que intenta demostrar que existe una finalidad legitima. Este trabajo trata los supuestos de discriminación directa e indirecta que sufren los deportistas y las vías de solución posibles como la conciliación, la acomodación razonable y el arbitraje, partiendo de que la dignidad bumana debe ser el fundamento de referencia para dar cohesión en una sociedad donde las libertades en materia de religión y de creencias entran en conflicto.
\end{abstract}

Palabras clave: deporte, religión, discriminación, libertades individuales, derechos fundamentales, deportistas, libertad religiosa.

\section{ABSTRACT}

Individual demonstrations of faith, whether of a sport nature or not, make part of the right to freedom of religion, which, as root to most freedoms, involves conscience and freedom of expression. Regarding competitive sportspeople we face probibitions supporting a neutral ground of ideologies and beliefs so as to make identity out of common ground toward peace and development. Conflict is clear, individual freedoms of people with their own identity facing an aseptic world which tries proving there is such a thing as a legitimate purpose. The current piece of work deals with direct and indirect discrimination against sportspeople together with the likely ways of conciliation, reasonable accommodation and arbitration, based on the fact that human dignity must be the flagship in this society where freedom based on faith and beliefs crash into one another.

Keywords: Sport, Religion, Discrimination against People, Individual Freedom, Fundamental Rights, Sportspeople, Right to Freedom of Religion. 


\section{ZUSAMMENFASSUNG}

Die religiösen Äußerungen von Menschen, ob Sportler oder nicht, sind Teil der Ausübung der Religionsfreibeit, die in der Freibeit wurzelt und die Gewissensund Meinungsfreibeit beinbaltet. Im Fall der Profisportler finden wir Verbote, die einen Raum frei von Ideologien und Überzengungen verteidigen, um einen Identitätsraum zu schaffen, der aus gemeinsamen Werten bestebt, die zu Frieden und Entwicklung beitragen. Der Konflikt ist offenkundig: die individuellen Freibeiten der Menschen mit ibrer eigenen Identität kollidieren mit einer aseptischen Welt, die versucht zu beweisen, dass sie einen legitimen Zweck verfolgt. Diese Arbeit befasst sich mit den Fällen direkter und indirekter Diskriminierung, die Sportler erleiden, und mit möglichen Lösungen wie Schlichtung, angemessene Vorkehrungen und Schiedsverfabren, auf der Grundlage, dass die Menschenwürde die Bezugsgrundlage sein muss, um den Zusammenhalt in einer Gesellschaft zu gewäbrleisten, in der die Freibeiten in Bezug auf Religion und Glauben in Konflikt geraten.

Schlüsselwörter: Sport, Religion, Diskriminierung, individuelle Freiheiten, Grundrechte, Athleten, Religionsfreiheit.

SUMARIO: I. INTRODUCCIÓN AL TEMA DE LAS MANIFESTACIONES RELIGIOSAS DE LOS DEPORTISTAS Y LA NEUTRALIDAD EN EL DEPORTE.-II. EL INTERÉS DEL DEPORTE.-1. El interés público y privado del deporte a nivel internacional.-2. El interés público y privado del deporte en España.-2.1. La organización en el deporte español y sus competencias respecto a los deportistas y asociados.-2.2. Interés social del deporte en España.-III. LA LIBERTAD DE CONCIENCIA RELIGIOSA Y DE EXPRESIÓN DEL DEPORTISTA ANTE LA DISCRIMINACIÓN DIRECTA E INDIRECTA.-1. El delicado equilibrio de las reglas neutrales, la igualdad y la libertad en el deporte.-1.1. Símbolos: intereses del empresario, razones de neutralidad y de orden público.-1.2. Prácticas religiosas que afectan al rendimiento.-1.3. Derecho de libertad de expresión y sus límites ¿neutralidad o discriminación?-2. Discriminación directa e indirecta de las libertades y derechos fundamentales en el ámbito laboral.-2.1. Normativa española.-2.2. Normativa internacional y europea. Su repercusión en España.-2.2.1. Definiciones y alcance general en la lucha contra la discriminación.-2.2.2. Discriminación y manifestaciones religiosas en el ámbito laboral y su aplicación al deporte profesional. Especial referencia a la discriminación indirecta.-a) Definición y contexto general.-b) Los derechos humanos y las leyes antidiscriminatorias. $-c$ ) Consecuencias penales en caso de discriminación por razón de religión y los actos que incitan a la violencia, al acoso y al odio.- - d) Justificación de la discriminación.-e) Medidas especiales para corregir la desigualdad. - f) La acomodación razonable.-IV. CONCLUSIONES.-1. La neutralidad del deporte y la identidad del deportista.-2. La libertad de conciencia religiosa en el uso de símbolos y la expresión de las convicciones religiosas.-3. La prescripción por ley de la limitación a los derechos humanos.-4. La discriminación directa e indirecta en el ámbito laboral y su estudio en el espacio deportivo.- - 5. La acomodación razonable de la libertad de conciencia religiosa.-6. El deporte como hacedor de la paz.-V. REFERENCIAS BIBLIOGRÁFICAS. 


\section{INTRODUCCIÓN AL TEMA DE LAS MANIFESTACIONES RELIGIOSAS DE LOS DEPORTISTAS Y LA NEUTRALIDAD EN EL DEPORTE}

Los conflictos entre derechos humanos en el área de la libertad de religión y de creencia nos obliga a centrarnos en el fundamento del orden político y de la paz social; nos referimos a la dignidad humana como motor impulsor de la cohesión social ${ }^{1}$. Cuando se producen tensiones por las manifestaciones religiosas de los deportistas en el espacio neutral del mundo del deporte, solo la dignidad del ser humano nos puede auxiliar para minimizar el conflicto.

El deporte es algo esencialmente social que crea lazos de parentesco entre personas muy diversas, y desde un punto de vista antropológico es cultura. Para algunos tiene un aspecto religioso y está cargado de simbolismo tanto en el espacio como en el lenguaje que se utiliza. Concretamente en el futbol, sus oficiantes o líderes se santiguan al pisar el terreno de juego, y también a algún estadio ${ }^{2}$ se le denomina como «catedral del fútbol»; de hecho, se dice que el decrecimiento de la afiliación religiosa se ha sustituido por la afición y afiliación deportiva ${ }^{3}$, aunque muchos todavía viven la fe religiosa integrada en todos los ámbitos de sus vidas, incluido el deporte como ocio o profesión, de lo que se derivan imperativos de conciencia.

Sin embargo, el Comité Olímpico Internacional (en adelante, COI) asumió medidas e impedimentos en materia religiosa al prohibir que durante los Juegos Olímpicos de 2012 se introdujeran en los estadios sitios de entrenamientos y lugares de reunión entre los atletas, así como cualquier impreso o libro de carácter religioso. Llegó la neutralidad al COI; sin embargo, ¿debe imponerse la neutralidad a los deportistas? Ciertamente, los atletas hicieron en aquel 2012 un derroche de gestos, actitudes y diferentes mani-

${ }^{1}$ Este trabajo se desarrolla dentro del PID2019-106005GB-100. Dignidad humana y cohesión social: vías para minimizar el efecto socialmente divisivo de los conflictos entre derechos humanos en el área de la libertad de religión y de creencias. IP. Javier Martínez Torrón.

2 R. Cachán Cruz y O. Fernández Álvarez, «Deporte o Religión: un análisis antropológico del fútbol como fenómeno religioso», Apunts. Educación Física y Deportes, núm. 52 (1998), p. 11.

3 N. H. Duru, «For Fear of the Fans: An Argument for Holding Sports Teams Accountable for Fans' Post-Match Conduct», Texas Review Entertainment \& Sports, vol. 20, núm. 1 (2019), p. 6. 
festaciones religiosas. Esta severidad secular constituye una religión propia $^{4}$, a lo que se suma la religión del deporte ${ }^{5}$, el nuevo opio para el consumo de masas que al igual que la religión se imbuye de simbolismo y de ritual $^{6}$ desde sus orígenes ${ }^{7}$, con intersecciones significativas ${ }^{8}$.

En los deportes, hay imágenes y símbolos, como emblemas, escudos, pegatinas, bufandas, muñecos, tatuajes, trofeos, camisetas y toda una serie de artículos, que representan algo con lo que nos identificamos.

El significado del deporte puede determinarse igualmente bajo la óptica de sus relaciones con el ritual, la ceremonia del acontecimiento? Comienza una sustitución por los ritos laicos a nivel institucional ${ }^{10}$, pero las personas, los deportistas y los amantes del deporte pueden tener una percepción religiosa de sus vidas, siendo la práctica del deporte y la participación en competiciones una expresión religiosa más ${ }^{11}$.

Aunque la libertad de expresión, según Malik, «is not just an important liberty but the very foundation of liberty ${ }^{12}$, muy distinta es la embriaguez casi romántica de mirar al cielo antes de una competición o de cualquier reto deportivo, de la utilización del deporte para incitar al odio a través

${ }^{4}$ En este sentido, A. OlLero, «Religious Symbols in Public Spaces: Ethical and Legal Arguments», en I. Olza, Ó. LourEda y M. CASADO (eds.), Language Use in the Public Sphere. Methodological Perspectives and Empirical Applications, colección «Linguistic Insights: Studies in Language and Communication», núm. 170, Bern, Peter Lang, 2013, p. 19.

${ }^{5}$ Coubertin, el fundador del olimpismo moderno, afirmó en 1910 que el deporte era una religión, según estudia O. SuÁrez GonZÁlez, La Inmunidad Olímpica. La violación de derechos de los deportistas y la propuesta para la creación de un mecanismo jurídico de protección, p. 35, disponible en http://hdl.bandle.net/10803/586254 (consultado el 15 de febrero de 2020).

${ }^{6}$ A. W. Coron, The parallel of Modern-Day Sport to Religion: an analysis of how society has transformed sport into a spiritual practice, disponible en https://wakespace.lib.wfu. edu/bitstream/handle/10339/39285/Williams_wfu_0248M_10569.pdf (consultado el 12 de marzo de 2020).

7 S. GARDInER et al., Sports Law, 2011, 4. a ed., London, Routledge, p. 15.

8 T. J. TRothen, «Sport, Spirituality, and Religion: New Intersections», Religión, vol. 10, núm. 10 (2019), pp. 545 y ss.; vid. https://doi.org/10.3390/rel10100545 (consultado el 14 de marzo de 2020); AA.VV., With God on their Side Sport in the Service of Religion, London, Routledge, 2002, https://doi.org/10.4324/9780203995341.

9 Para Douglas, el ritual, al igual que el lenguaje, actúa como transmisor de la cultura y ejerce un efecto coercitivo sobre el comportamiento social. M. Douglas, Símbolos naturales, Madrid, Alianza, 1970.

${ }^{10}$ Aunque algunos estadios, como el Wanda del Atlético de Madrid o el del Rayo Vallecano, tengan capillas en el interior de sus dependencias.

${ }^{11}$ En este sentido, R. S. Obare, Can Sports Exist Without Religion?, disponible en bttps://www.sheffield.ac.uk/polopoly_fs/1.71451!/file/obare.pdf (consultado el 13 de marzo de 2020).

${ }^{12}$ K. MaLIK, From Fatwa to Jihad: The Rushdie Affair and Its Legacy, London, Atlantic, 2009, p. 155. 
del discurso ${ }^{13} \mathrm{o}$ de símbolos para generar violencia contra personas o grupos de personas por razón de religión o de creencias $^{14}$, evidenciando una lacra en la educación ${ }^{15}$.

Ahora bien, la radicalización de prohibir todos los símbolos con el fin de no ofender a alguna religión en particular no parece ser algo que encaje en el deporte. La pedagogía social que se ejerce a través del deporte no parece que se dirija a esterilizar la fecunda libertad religiosa de las personas con asépticas prohibiciones de carácter político como si fuera un simple negocio, ya que sus lecciones van más allá de lo empresarial. Se precisa una «acomodación razonable» que no genere perjuicios a terceros, que no sea discriminatorio e injusto para otros, debido a la diversidad de culturas que conviven en el deporte, la pluralidad de razas, credos y lenguas.

Las demandas legales y los argumentos basados en la conciencia religiosa continúan proliferando en el deporte incluso en sacrificios como el ayuno o en días de descanso con carácter religioso, tal y como sucede en cualquier ámbito laboral ${ }^{16}$. Quizá convenga acomodar a los individuos como una modesta extensión del derecho a la objeción de conciencia ya reconocida con respecto al servicio militar y al aborto al aplicarlo en el contexto de actos moralmente controvertidos, porque se expresan en términos no negociables, lo que implica que las acciones motivadas por la conciencia merecen una forma especial de protección legal, aunque apli-

13 «El TEDH, siguiendo las tendencias internacionales predominantes, ha declarado inequívocamente que el lenguaje de odio no constituye una parte integrante de la libertad de expresión garantizada por el Convenio Europeo de Derechos Humanos. Es decir, va más allá de la mera afirmación de que el hate speech puede ser limitado legítimamente por los Estados, en uso de su margen de apreciación, de acuerdo con el art. 10.2 CEDH. Lo que el Tribunal subraya es que no goza de ninguna manera de la protección del art. 10.1 CEDH» (J. MARTínez TORRón, «¿Libertad de expresión amordazada? Libertad de expresión y Libertad de Religión en la jurisprudencia de Estrasburgo», Tensiones entre libertad de expresión y libertad religiosa. Valencia, Tirant lo Blanch, 2014, pp. 114-115.

${ }^{14}$ I. M. BRiones MARTínez, El delito de odio por razón de religión y de creencias. La educación en la religión contra el terrorismo de la palabra y de la violencia, Madrid, Thomson Reuters, 2018, y R. García García, G. David Docal, E. Ibarra y T. Calvo Buezas, Grupos de odio y violencias sociales, Madrid, Rasche, 2012.

15 «Working session 7: Tolerance and non-discrimination I, including: combating racism, xenophobia, and discrimination; combating anti-Semitism and intolerance and discrimination against Christians, Muslims and members of other religions; prevention and responses to hate crimes in the OSCE area», disponible en bttps://www.osce.org/ odibr/343771? download=true (consultado el 15 de marzo de 2020=, pp. 18-19.

${ }_{16}$ I. Minteguía ArRegui, «Diversidad cultural y deporte profesional», en M. ${ }^{a}$ A. CASTRO Jover (dir.), Interculturalidad y Derecho, Cizur Menor, Aranzadi, 2013, pp. 182-191.

Foro, Nueva época, vol. 23, núm. 1 (2020): 155-220 
cando el principio de igualdad y no discriminación también deba acomodarse a los actos según creencias no religiosas ${ }^{17}$.

A pesar de la ventajosa fórmula de la acomodación razonable, se tiende a desjudicializar la conciencia también mediante la conciliación entre las partes ${ }^{18}$.

\section{EL INTERÉS DEL DEPORTE}

\section{El interés público y privado del deporte a nivel internacional}

El programa provisional del quincuagésimo octavo periodo de sesiones de la Asamblea General a solicitud de Túnez (A/58/142) incluyó el tema titulado «Año Internacional del Deporte y la Educación Física» ${ }^{19}$. Asimismo, la Resolución de Naciones Unidas núm. 58/5, titulada «El deporte como medio para fomentar la educación, la salud y el desarrollo y la paz» ${ }^{20}$, se complementa con el reconocimiento de que los Juegos Olímpicos contribuyen al entendimiento entre los pueblos y las civilizaciones, y acoge con beneplácito a este respecto la contribución de los Juegos Olímpicos de 2004 organizados en Atenas.

${ }_{17}$ Consultar sobre el tema a A. DONALD y E. HOWARD, The right to freedom of religion or belief and its intersection with other rights, paper for ILGA-Europe, 2015, pp. 1-21.

${ }_{18}$ Por la idea de la conciliación está el Informe Canadiense Bouchard-Taylor, en el que propone lo siguiente: «El ámbito de las prácticas de armonización es complejo y hay más de una forma de definirlo o describirlo. Hemos optado por dar prioridad al marco de tratamiento de las demandas, lo que nos conduce a distinguir la vía judicial de la vía ciudadana. En la vía judicial, las demandas deben plegarse a mecanismos formales codificados que utilizan las partes una contra otra y, que a fin de cuentas, decretan un ganador y un perdedor. La mayoría de las veces, en efecto, los tribunales imponen decisiones. Esta vía judicial es la del acomodo razonable. En la segunda vía, las demandas siguen un recorrido muy diferente. Menos formal, esta trayectoria se basa en la negociación y la búsqueda de compromiso. Su objetivo es llegar a una solución que satisfaga a las dos partes. Esta segunda vía es la del ajuste concertado. De manera general, nosotros favorecemos fundamentalmente el recurso a la vía ciudadana y al ajuste concertado y ello, por varias razones: a) es bueno que los ciudadanos aprendan a gestionar sus diferencias y sus desacuerdos; $b$ ) esta vía evita congestionar los tribunales; c) los valores que sostienen la vida ciudadana (intercambios, negociación, reciprocidad...) son los mismos que sustentan el interculturalismo. En el plano cuantitativo, se constata por otra parte que la mayor parte de las demandas toma la vía ciudadana (y solamente un pequeño número sigue la vía de los tribunales)». Cfr. https://www.ikuspegi. eus/documentos/investigacion/es/txostena5_cas.pdf (consultado el 10 de octubre de 2019).

19 https://undocs.org/es/A/58/142 (consultado el 20 de octubre de 2019).

${ }^{20} \mathrm{La}$ Asamblea decidió que se convirtiera en el subtema $b$ ) de un nuevo tema titulado «El deporte para la paz y el desarrollo» (decisión 58/503 A) Prosiguió el examen del subtema en sus periodos de sesiones quincuagésimo noveno y sexagésimo (resoluciones 59/10 y 60/9). 
La Resolución 60/921 reconoce que el deporte y la educación física pueden ofrecer oportunidades de solidaridad y cooperación a fin de fomentar la tolerancia, una cultura de paz, la igualdad social y de género. Por ello, los gobiernos, el sistema de las Naciones Unidas y las organizaciones deportivas internacionales alientan a seguir desarrollando un marco mundial para fortalecer una visión común, definir prioridades y promover una mayor conciencia con el fin de mejorar e integrar políticas relacionadas con el deporte como medio de promover el desarrollo y la paz que sean de fácil aplicación ${ }^{22}$.

En 2017, la Sexta Conferencia Internacional de Ministros y Altos Funcionarios Encargados de la Educación Física y el Deporte, convocada por la Organización de las Naciones Unidas para la Educación, la Ciencia y la Cultura (UNESCO), aprobó el Plan de acción de Kazán ${ }^{23}$ con tres esferas, una de ellas su contribución al desarrollo sostenible y a la paz, además de diez objetivos y treinta y seis metas asociadas al deporte ${ }^{24}$.

El Consejo de Derechos Humanos decidió incorporar en su programa de trabajo una mesa redonda temática en torno a la promoción de los derechos humanos mediante el deporte y el ideal olímpico ${ }^{25}$. El Foro Social del Consejo de Derechos Humanos también estudió en octubre de 2018 las posibilidades de utilizar el deporte y el ideal olímpico para promover los derechos humanos para todos y fomentar el respeto universal de estos. En la misma línea, la Asamblea General aprobó igualmente la Resolución $72 / 6$, titulada «Construcción de un mundo pacífico y mejor mediante el deporte y el ideal olímpico».

Sin duda, el deporte como lenguaje universal supone el acceso y la participación para la población marginada por barreras sociales, culturales y religiosas; educa la personalidad de los jóvenes deportistas, siendo «motor de diálogo intercultural, preservando y protegiendo las tradiciones culturales e incluso ancestrales, como las que vienen ya de los juegos indígenas, lo que entraña una "educación de alta calidad"».

Si nos centramos en el Consejo de Europa también encontramos un especial interés en el deporte. Destacan documentos como la Resolu-

${ }^{21}$ Resolución 59/10. Cfr. https://undocs.org/es/A/RES/60/9 (consultado el 20 de octubre de 2019).

22 https://undocs.org/es/A/RES/61/10 (consultado el 20 de octubre de 2019); bttps:// undocs.org/es/A/48/237 (consultado el 20 de octubre de 2019).

23 https://unesdoc.unesco.org/ark:/48223/pf0000252725_spa (consultado el 20 de octubre de 2019).

24 https://es.unesco.org/mineps6/kazan-action-plan (consultado el 20 de octubre de 2019).

${ }^{25}$ Resolución 37/18. Cfr. bttps://undocs.org/pdf?symbol=es/A/73/477, p. 20 (consultado el 15 de abril de 2021) 
ción 682 (1975), relativa a una «Carta Europea del Deporte para todos»; la «Carta Europea del Deporte» aprobada en la VII Conferencia de Ministros responsables para el deporte de los países europeos (Rodas, 1992); el «Código de la Ética del Deporte» con el lema: «El que juega limpio siempre sale ganando», y la «Convención Antidopaje» (1990), que fijan el marco y el nivel de la concepción europea sobre el deporte en tanto que un deporte fiel al juego limpio, accesible para todos, desconocedor de toda discriminación, ético, tolerante, sano y seguro ${ }^{26}$.

La Carta Europea de 1992 realiza una declaración de «diversidad» en el mundo del deporte, aunque se busque una identidad cultural europea a través del mismo.

Destaca igualmente el Libro Blanco del Deporte de la Unión Europea ${ }^{27}$, publicado el día 11 de julio de 2007 por la Comisión de las Comunidades Europeas. En el punto 2.6 sobre refuerzo de la prevención y la lucha contra el racismo y la violencia afirma que el deporte concierne a todos los ciudadanos, independientemente de su religión y creencia.

El Parlamento Europeo aprobó la Resolución de 2 de febrero de $2017^{28}$ sobre un enfoque integrado de la política del deporte: buena gobernanza, accesibilidad e integridad [2016/2143(INI)], en la que se considera que el deporte también contribuye a la integración de las personas y trasciende la raza, la religión y la etnicidad.

Con el Tratado de Lisboa, la Unión Europea adquirió una competencia específica en materia de deporte. El art. 6.e) del Tratado de Funcionamiento de la Unión Europea (TFUE) confiere a la Unión la competencia para llevar a cabo actividades con el fin de apoyar o complementar las acciones de los Estados miembros en el ámbito del deporte, mientras que el art. 165, apartado 1, describe pormenorizadamente la política de deporte, declarando que la Unión se encaminará a «desarrollar la dimensión europea del deporte promoviendo la equidad y la apertura en las competiciones deportivas y la cooperación entre los organismos responsables del deporte, y protegiendo la integridad física y moral de los deportistas, especialmente la de los más jóvenes».

${ }^{26}$ B. KuniCKA-MichaLSKA, «La lucha contra la violencia que se produce en las manifestaciones deportivas», Eguzkilore: Cuaderno del Instituto Vasco de Criminología, núm. 18 (2004), pp. 43-58.

27 https://eur-lex.europa.eu/legal-content/ES/TXT/? uri=LEGISSUM\%3Al35010 (consultado el 15 de enero de 2020). También se elaboró el Plan de Acción «Pierre de Coubertin».

28 https://www.europarl.europa.eu/doceo/document/TA-8-2017-0012_ES.html (consultado el 3 de febrero de 2020). 
Por otra parte, las competencias de la Unión en el ámbito del mercado único también han tenido un impacto considerable en el deporte. Así, por ejemplo, el Tribunal de Justicia de la Unión Europea ha ido desarrollando una jurisprudencia significativa con repercusiones importantes en el mundo del deporte (como el asunto Bosman ${ }^{29}$ y el caso Kolpak $k^{30}$ ).

Todas las buenas declaraciones que hemos mencionado no son fáciles de gestionar para su cumplimiento, ya que los órganos que lideran el deporte desarrollarán mecanismos de decisión autónoma (como figura en el art. 3), aunque ello no deba suponer la explotación del deporte ni del deportista, por lo que se apela a los principios éticos del código de ética deportiva en su art. 1.ii), donde se preconiza la necesidad de salvaguardar y desarrollar los fundamentos morales y éticos del deporte, asî como la dignidad humana y la seguridad del deportista. Esta disyuntiva entre los derechos fundamentales del deportista que se basan en su dignidad humana y la autonomía de las organizaciones deportivas para cuestiones reglamentarias y de disciplina es la que se plantea si aplicamos la doctrina norteamericana del interés público predominante para limitar la libertad religiosa y de conciencia o la del «balance» entre ambos intereses, sabiendo que los derechos fundamentales, además de ser personales y subjetivos, su garantía constituye una cuestión de interés público. Pues bien, no existiendo una normativa específica en España, se debe atender al caso concreto; sin embargo, esperar que un tribunal administrativo decida como una especie de tribunal de conciencia al modo anglosajón ${ }^{31}$ no es una solución fácil, de modo que, aun tratándose de derechos fundamentales, quizá la solución más justa provenga de la conciliación de posiciones a través del laudo arbitral, que podría ser el instrumento para canalizar la acomodación razonable entre las partes sin llegar a la vía judicial, un nivel intermedio y que conocemos como arbitraje laboral ${ }^{32}$.

${ }^{29}$ Sentencia TJUE, de 15 de diciembre de 1995. Vid. J. de D. CRESPo Pérez, «El caso Bosman: sus consecuencias», Revista General Informática de Derecho, núm. 622-623 (1996), pp. 8093-8120.

${ }^{30}$ Sentencia TJUE, de 8 de mayo de 2003, disponible en bttps://eur-lex.europa.eu/legalcontent/ES/TXT/PDF/?uri=CELEX:62000CJ0438Efrom=EN (consultado el 12 de diciembre de 2019).

31 J. MARTínez- TORRÓn, Derecho angloamericano y Derecho canónico. Las raíces canónicas de la «common law», Madrid, Servicio publicaciones de la Facultad de Derecho-Civitas, 1991, pp. 67-92.

32 En nuestro ordenamiento el arbitraje laboral no es único, sino que existen diversas modalidades previstas por ley. Vid. sobre el arbitraje laboral https://www.iberley.es/temas/ arbitraje-laboral-2871 (consultado el 5 de mayo de 2020). 


\section{El interés público y privado del deporte en España}

\subsection{La organización en el deporte español y sus competencias respecto a los deportistas y asociados}

El art. 43 de la Constitución española establece en su núm. 3: «Los poderes públicos fomentarán la educación sanitaria, la educación física y el deporte. Asimismo, facilitarán la adecuada utilización del ocio». Lo engloba dentro de las acciones para hacer efectivo el derecho a la protección de la salud, que es una cuestión de interés público y, por supuesto, privado.

Necesitamos conocer la organización en el deporte español para llegar hasta el tema que este trabajo investiga: cómo se garantizan o se restringen la libertad religiosa y las actuaciones por razones de conciencia en el deporte ${ }^{33}$.

Aunque se espera una nueva Ley del Deporte, de momento rige la Ley 10/1990, de 15 de octubre ${ }^{34}$, y en su art. 6 establece que «el deporte de alto nivel se considera de interés para el Estado, en tanto que constituye un factor esencial en el desarrollo deportivo, por el estímulo que supone para el fomento del deporte base, en virtud de las exigencias técnicas y científicas de su preparación, y por su función representativa de España en las pruebas o competiciones deportivas oficiales de carácter internacional».

La actuación de la Administración del Estado en el ámbito del deporte corresponde y será ejercida directamente por el Consejo Superior de Deportes, que es un organismo autónomo de carácter administrativo adscrito al Ministerio de Educación y Ciencia. Reglamentariamente el Gobierno podrá modificar esta adscripción (art. 7).

33 «Otro punto de conflicto se suscita en torno a si es posible que, teniendo en consideración determinados intereses empresariales, estos puedan ser fundamento para una limitación de las expresiones religiosas, individuales y colectivas, o para regular restrictivamente el uso de atuendos, símbolos, o señales, o apariencias físicas que identifiquen una religión concreta. Por último, el posible conflicto entre el ejercicio del derecho fundamental a la libertad religiosa y las exigencias de la organización productiva, esencialmente en cuanto a la organización del trabajo, las pausas, los horarios y los tiempos de trabajo y de descanso» [S. GONZALO ORTEGA, «Libertad religiosa y contrato de trabajo en la jurisprudencia del Tribunal Europeo de Derechos Humanos», Temas Laborales, núm. 145 (2018), p. 196].

${ }^{34}$ BOE, núm. 249, de 17 de octubre de 1990. 
Siguiendo la organización establecida en los arts. 12 y 13 de la Ley del Deporte $^{35}$, para saber si un club puede prohibir manifestaciones religiosas a sus deportistas o asociados solo tenemos como dato el art. 17, que obliga para la constitución de un club deportivo básico que se presenten sus Estatutos en el Registro ${ }^{36}$, en los que deberá constar, como mínimo respecto a lo que nos interesa: «b) requisitos y procedimiento de adquisición y pérdida de la condición de socios; c) derechos y deberes de los socios; [...] f) régimen disciplinario».

Si hablamos de clubes también hablamos de ligas. Las ligas profesionales tendrán personalidad jurídica y gozarán de autonomía para su organización interna y funcionamiento respecto de la federación deportiva española correspondiente de la que formen parte.

También nos interesa que puedan establecer unas reglas de comportamiento. Los estatutos y reglamentos de las ligas profesionales serán aprobados por el Consejo Superior de Deportes, previo informe de la federación deportiva española correspondiente, debiendo incluir, además de los requisitos generales señalados reglamentariamente, un régimen disciplinario específico.

Según el art. 41, son competencias de las ligas profesionales, además de las que pueda delegarles la federación deportiva española correspondiente, la de organizar sus propias competiciones, y lo más importante en lo que nos interesa para este trabajo: «b) desempeñar, respecto de sus asociados, las funciones de tutela, control y supervisión establecidas en la presente ley; c) ejercer la potestad disciplinaria en los términos previstos en la presente ley y sus disposiciones de desarrollo».

Según el art. 73, a nivel institucional, de igual forma se debe responder por infracciones. «Se considerarán, en todo caso, como infracciones muy graves a las reglas de juego o competición o a las normas deportivas generales: a) el incumplimiento reiterado de órdenes e instrucciones emanadas de los órganos deportivos competentes; $b$ ) los actos notorios y públicos que atenten a la dignidad o decoro deportivos» (art. 76.4). «Se considerarán infracciones de carácter leve las conductas claramente contrarias a las

35 Vid. arts. 12 y 13 .

${ }^{36} \mathrm{El}$ art. 18 también nos habla de entidades públicas o privadas, dotadas de personalidad jurídica, o grupos existentes dentro de las mismas, que se hayan constituido de conformidad con la legislación correspondiente, y que podrán acceder al Registro de Asociaciones Deportivas cuando desarrollen actividades deportivas de carácter accesorio en relación con su objeto principal. 
normas deportivas, que no estén incursas en la calificación de muy graves o graves» (art. 76.5).

Para todos, incluidos deportistas y asociados, el art. 79 nos dice que:

«1. Las sanciones susceptibles de aplicación por la comisión de infracciones deportivas correspondientes serán las siguientes: $[. .$.$] e) las de pro-$ hibición de acceso al estadio, pérdida de la condición de socio y celebración de la competición deportiva a puerta cerrada; f) la de apercibimiento, en los casos en que el deportista, aun habiendo facilitado los datos exigidos en el art. 58.1 de esta Ley, no sea localizado hasta en tres ocasiones».

Si el deportista o los asociados a clubes cometen infracciones disciplinarias es el «Tribunal Administrativo del Deporte» el que decide. Se trata de un órgano de ámbito estatal, adscrito orgánicamente al Consejo Superior de Deportes.

Las cuestiones litigiosas de naturaleza jurídico-deportiva planteadas o que puedan plantearse entre los deportistas, técnicos, jueces o árbitros, clubes deportivos, asociados, federaciones deportivas españolas, ligas profesionales y demás partes interesadas podrán ser todas resueltas mediante la aplicación de fórmulas específicas de conciliación o arbitraje, en los términos y bajo las condiciones de la legislación del Estado sobre la materia. Las resoluciones adoptadas en estos procedimientos tendrán los efectos previstos en la Ley de Arbitraje.

Ante la evidente judicialización de decisiones políticas sobre libertad religiosa en una sociedad diversa ${ }^{37}$, habría que preguntarse si la prohibición del ejercicio de la libertad religiosa, como es una manifestación de la fe, a través del discurso propio de la libertad de expresión, de símbolos o de algún ritual, podría considerarse desde la perspectiva de la disciplina, tramitándose ante un simple tribunal administrativo o por las reglas del arbitraje. ¿Realmente podemos dejar los derechos fundamentales de la mano de la potestad de tribunales inferiores o de un laudo arbitral? Recordemos asimismo que el arbitraje y la acomodación razonable van a la inversa, ya que esta supone la judicialización. El arbitraje parece un medio alternativo ante sujetos iguales ante la ley, y aunque queda lejos el poder divino

37 «The phrase "judicialization of politics" refers to the fact that in many modern societies, courts rather than legislative or executive branches decide major political issues (Hirschl 2006; Tate and Vallinder 1995). Indeed, in some societies courts have assumed a role of "ultimate decider", with the ability to overrule executive directives and legislation passed by legislatures» (J. T. RicHARDSON, «Managing Religion and the Judicialization of Religious Freedom», Journal for the Scientific Study of Religion, vol. 54, núm. 1 (2015), p. 4. 
del empleador sobre la vida de sus empleados, que son considerados personas, e incluso tienen derecho al libre desarrollo de la personalidad en su lugar de trabajo ${ }^{38}$, no parece tan fácil obtener un laudo arbitral que satisfaga a ambas partes cuando el derecho al trabajo se ve comprometido por el ejercicio de la libertad religiosa si se contrapone a los intereses del empleador y su libertad de organización interna.

Todo queda en manos de competencias derivadas de estatutos, pero no expresamente declaradas en los mismos porque no hay referencia alguna a una prohibición de manifestaciones ideológicas y/o religiosas, ni descripción sobre lo que son actos notorios y públicos que atentan a la dignidad o decoro deportivos, de ahí que se exigiría una interpretación constitucional seria y rigurosa, por vía legislativa o jurisprudencial, de lo que se entiende por dignidad o decoro deportivo para que podamos incluir dichas manifestaciones en el ejercicio de un derecho fundamental como un atentado al mismo y medir o establecer un balance de intereses jurídicos, ya que son una manifestación del pluralismo, por lo que no pueden ofender al mismo, y aunque así fuera, recordemos la Sentencia del Tribunal Europeo de Derechos Humanos de 7 de diciembre de 1976, caso Handyside, en la que se defiende la libertad de expresión —en la que podemos incluir la religiosa- y se afirma que es uno de los fundamentos esenciales de la sociedad, incluso si son ideas que ofenden al Estado o a una parte de la población, porque lo reclama el pluralismo, la tolerancia y el espíritu de apertura, sin las cuales no existe una sociedad democrática. Se considere un derecho de protección o de promoción, lo cierto es que solo se puede limitar si hay un fin proporcionalmente legítimo en una sociedad democrática (como la seguridad o cualquier elemento integrante del orden público, entre ellos la salud) y, a pesar de la autonomía de los clubes, habría que tener unos cánones objetivos sobre la dignidad y el decoro deportivo para determinar si es un interés superior al ejercicio de la libertad religiosa y de expresión, así como a su contenido o mensaje tanto corporal como de palabra, que se convierte para el ser humano en una cuestión de identidad y de conciencia.

38 Vid. sobre este tema la recensión de M. W. Finkink a la obra de Menschenbild, «Menschenbild: The conception of the employee as a person in western law», Comparative Labor Law E Policy Journal, vol. 23, núm. 2 (2002), pp. 577-638. 


\subsection{Interés social del deporte en España}

2.2.1. El interés público y social de la lucha contra la violencia, el racismo, la xenofobia y la intolerancia en el deporte español

En el Preámbulo de la Ley 19/2007, de 11 de julio, contra la violencia, el racismo, la xenofobia y la intolerancia en el deporte ${ }^{39}$, se declara que ninguna raza, religión, creencia política o grupo étnico puede considerarse superior a las demás. Y en este aspecto, lo que ocurra en el deporte ha de reflejar los valores en que se sustenta nuestra convivencia democrática.

Siguiendo esta recomendación, tanto la Federación Internacional de Fútbol Asociado como la Federación Europea de Fútbol Asociado se han esforzado de manera muy decidida en promocionar la igualdad de trato de las comunidades étnicas y grupos de inmigrantes, con el objetivo de reafirmar la condición del fútbol como un deporte universal, un espectáculo abierto a la participación de todas las personas, ya sea como jugadores o como espectadores, sin temor alguno y con garantías de no ser insultados, acosados o discriminados por su origen, por el color de la piel, por su orientación sexual o sus creencias religiosas.

Se establecieron en el capítulo VI las funciones de distinto orden a realizar por la nueva Comisión Estatal contra la Violencia, el Racismo, la Xenofobia y la Intolerancia en el Deporte, que sustituirá a la Comisión Nacional. Ya que las manifestaciones religiosas pueden encarnarse en un discurso con lenguaje religioso o a través de símbolos, la normativa se encarga de establecer cuándo se configura como delito ${ }^{40}$, y de ella se des-

\footnotetext{
39 https://www.boe.es/buscar/doc.php?id=BOE-A-2007-13408 (consultado el 12 de enero de 2020).

${ }_{40}$ Me refiero al Real Decreto 203/2010, de 26 de febrero, por el que se aprueba el Reglamento de prevención de la violencia, el racismo, la xenofobia y la intolerancia en el deporte que en el núm. 2 del art. 20 sobre el anverso y reverso de las entradas prescribe que: «Las entradas indicarán en su reverso que el recinto deportivo es una zona vídeo vigilada para la seguridad de los asistentes y participantes en el encuentro, y especificarán las causas que impiden el acceso al recinto deportivo o la permanencia en el mismo, incorporando expresamente, como mínimo, las siguientes: $f$ ) Introducir, exhibir o elaborar pancartas, banderas, símbolos u otras señales con mensajes que inciten a la violencia o al terrorismo, o en cuya virtud una persona o grupo de ellas sea amenazada, insultada o vejada por razón de su origen racial o étnico, religión o convicciones, discapacidad, edad, sexo u orientación sexual. g) Realizar cánticos, expresiones, sonidos o actitudes que inciten a la violencia o al terrorismo, o que pretendan vejar a una persona o grupo de ellas por razón de su raza o etnia, discapacidad, religión o convicciones, sexo u orientación sexual».
} 
prende que solo se prohíbe si se demuestra que con dichas manifestaciones se incita a la violencia, al terrorismo, constituyen amenazas, insultos o vejaciones por razón de su religión o convicciones.

Para la vigilancia sobre estos actos contamos con diversos observatorios. Uno más específico del deporte como es el Observatorio de la Violencia, el Racismo, la Xenofobia y la Intolerancia en el Deporte y otro relativo a la libertad religiosa, el Observatorio del Pluralismo Religioso ${ }^{41}$.

Para erradicar la homofobia, la bifobia y la transfobia se ha realizado una proposición de ley por la que se modifica la Ley 19/2007, de 11 de julio, contra la violencia, el racismo, la xenofobia y la intolerancia en el deporte ${ }^{42}$, en la que también se prohíbe que una persona o grupo sean amenazados por razón de religión o por sus convicciones, o que sufran acoso por el mismo motivo. Se castigan los actos manifiestamente vejatorios, así como la entonación de cánticos, sonidos, consignas o exhibición de pancartas, banderas, símbolos u otras señales que contengan mensajes vejatorios o intimidatorios para cualquier persona por razón de la religión $y$ las convicciones ${ }^{43}$.

Con esta proposición de ley se perfilan mejor los tipos de delitos en el ámbito penal. Aunque en principio su finalidad va destinada a proteger a las personas vulnerables por razón de género, queda prohibida igualmente la discriminación por motivos de religión o convicciones. Ahora bien, no quedan amparados ningún mensaje, declaración, información, actuaciones, gestos, entonación de cánticos, pancartas, banderas, símbolos u otras señales de carácter religioso que supongan una amenaza, insulto o vejación a otros por razones de género, basadas en la homofobia, la bifobia y la transfobia, o cualquier otra causa prevista en la ley.

\subsubsection{Interés público e interés del público}

Habría que preguntarse si además de un interés empresarial existe un interés público. Pues bien, en realidad, la mayoría de los comités y organismos deportivos, en atención a su objeto, naturaleza y funciones en el ámbito deportivo, están declarados de utilidad pública por la legisla-

\footnotetext{
${ }^{41}$ http://www.observatorioreligion.es/ (consultado el 21 de noviembre de 2019).

42 http://www.senado.es/legis13/publicaciones/pdf/senado/bocg/BOCG_D_13_20_392. PDF (consultado el 16 de febrero de 2020).

${ }_{43}$ Dos. Se modifican las letras $a$ ), b), c), d), y f) del apartado 2 del art. 2 de Ley 19/2007, de 11 de julio, contra la violencia, el racismo, la xenofobia y la intolerancia en el deporte.
} 
ción española, y entre sus fines se incluye la organización y participación de los deportistas españoles en los Juegos del tipo que sean, destacando los Paralímpicos ${ }^{44}$.

Desde el Gobierno de España se ha concedido el reconocimiento de Acontecimientos de Excepcional Interés Público (AEIP) a cuatro programas deportivos, implicando también a las empresas: Universo Mujer, Apoyo al Deporte Base 2020 (ADB), Nuevas Metas y Deporte Inclusivo. Todos ellos son herramientas que hacen crecer el deporte al tiempo que transforman la sociedad, haciéndola más justa, más igualitaria y más inclusiva.

El interés público del deporte se discute por algunos expertos. Así, Sánchez Ferlosio publicaba en El Pais ${ }^{45}$ un artículo sobre «El deporte y el Estado», y con gran sarcasmo afirmaba que un interés privado, como es el del deporte, por multitudinario que sea el «interés del público» que llegue a concitar, jamás podrá convertirse en «interés público», pero sí, en cambio, en «interés de Estado». No estoy de acuerdo con la proyección del deporte en general como una cierta pedagogía social únicamente para crear una ideología nacionalista de victoria. Si hacemos un repaso a la historia, sí encontramos casos en los que así se ha utilizado el deporte, los juegos en general; sin embargo, a fecha de hoy vivimos en una sociedad diversa en la que la práctica del deporte fomenta valores de los que se beneficia la persona y la sociedad, y es un reflejo de la madurez de la política estatal en el compromiso de velar por la salud y los buenos hábitos de los ciudadanos.

Ciertamente, el deporte profesional también está imbuido de mercantilización y comercialización, de un gran interés empresarial que se sitúa más en el mundo del trabajo. Solo el deporte no profesional está al margen de la obsesión competitiva y se debe promover en el ámbito escolar como fuente de valores ${ }^{46}$.

${ }_{44}$ Real Decreto 610/2019, de 25 de octubre, por el que se regula la concesión directa de una subvención al Comité Paralímpico Español para la realización de actuaciones de interés público, disponible en bttps://www.boe.es/diario_boe/txt.php?id=BOE-A-2019-15406 (consultado el 4 de enero de 2020).

${ }^{45}$ En https://elpais.com/diario/1997/05/31/opinion/865029604_850215.btml (consultado el 3 de enero de 2020).

46 Vid. sobre el tema A. DíAz SuÁREZ, «El deporte, una solución a la multiculturalidad», Revista Iberoamericana de Educación, vol. 50, núm. 2 (2009), pp. 1-12. 


\section{LA LIBERTAD DE CONCIENCIA RELIGIOSA Y DE EXPRESIÓN DEL DEPORTISTA ANTE LA DISCRIMINACIÓN DIRECTA E INDIRECTA}

\section{El delicado equilibrio de las reglas neutrales, la igualdad y la libertad en el deporte}

Se exige la neutralidad en materia religiosa para evitar la discriminación directa, la minimización de la discriminación indirecta en la medida de lo posible, o al menos su compensación, y la no utilización de la religión como una fuente productiva de enriquecimiento, alentando el odio, la discriminación y la violencia.

La acomodación de la manifestación de creencias religiosas es diferente si el empresario es una persona física o jurídica sin ideario o si se trata de una institución religiosa o con un ideario de neutralidad. Esta última reivindica un particular espacio, ya sea un lugar de culto, una escuela o un hospital, como exento de reglas seculares que intenten entrar en su autonomía. En el supuesto de una empresa estatal secular, o de una persona física o jurídica sin ideario o con ideario neutral, ocurre lo opuesto, porque el profesional intenta introducir las manifestaciones de sus creencias religiosas en un espacio secular o, al menos, neutral.

Hemos sido testigos de muchos supuestos en los que la libertad religiosa e ideológica del deportista se enfrenta a la neutralidad que exige un club deportivo ${ }^{47}$, supuestamente por razones de Estado ${ }^{48}$. Las instituciones religiosas tienen un ideario propio que puede originar situaciones de indiscriminación indirecta para sus empleados; sin embargo, un Estado neutral en materia religiosa no puede adoptar como propia una ideología ni religión, solo es un Estado social de Derecho que debe respetar los derechos

47 «Consider, for example, the rivalry between the two prominent teams of Glasgow-Celtic and Rangers (also known as the "Old Firm"), whose support is traditionally predominantly Catholic and Protestant, respectively. The rivalry between the two Scottish teams attracts millions of people from all around the globe because of the religious and societal background of the matchup. This background provides the Old Firm derby with an "added value" beyond the game itself. The way in which FIFA refers to the clash between Celtic and Rangers may illustrate why institutional discrimination has marketing potential» (Y. Covo, «Beyond Individual Discrimination: Why FIFA fails to address discriminatory practices in world football», Texas Review of Entertainment and Sport Law, vol. 20, núm. 133 (2019), pp. 134 y p. 196).

${ }^{48}$ Ibid., p. 150. 
humanos y no imponer la neutralidad sobre las personas para que tengan un cerebro plano ${ }^{49}$.

\subsection{Simbolos: intereses del empresario, razones de neutralidad $y$ de orden público}

Un tipo de manifestaciones religiosas son los símbolos e indumentaria, así como el discurso religioso y político que se expresa portando tales símbolos o vistiendo una específica indumentaria. Si se hace negocio con las marcas de la indumentaria, incluso las zapatillas de deporte, impedir a los trabajadores, en este caso deportistas profesionales, que porten símbolos o indumentaria que reflejen su identidad o afiliación religiosa por razones de neutralidad es como prohibirles hacer visible su identidad, las diferencias culturales y la diversidad religiosa ${ }^{50}$. Sin embargo, en los conflictos de intereses, el razonamiento jurídico que lleve a una solución justa requiere sopesar cuál predomina, aunque ambos sean dignos de protección, porque en el ejercicio de nuestras libertades podemos causar un daño, como un atentado a la salud, a la seguridad pública o como medida preventiva de un delito. Así que depende del supuesto en concreto, ya que una prohibi-

49 «I will focus on "accommodating a particular manifestation of the beliefs of a religious individual", as opposed to a religious organization, which seeks to define a particular space (place of worship, school, hospital) as a collective religious space, and requests exemptions to prevent secular rules from entering and changing it. In the case of a religious individual, the opposite occurs: the individual brings the particular manifestation of their religious beliefs into a space that is otherwise secular. The challenge for human rights law is to allow the religious individual to participate to the greatest extent possible in public life, while ensuring that particular manifestations of their religious beliefs do not have the effect of imposing their beliefs on others» [R. WINTEMUTE, «Accommodating Religious Beliefs: Harm, Clothing or Symbols, and Refusals to Serve Others», Modern Law Review, vol. 77, núm. 2 (2014), p. 3 ].

50 «I would argue that public sector employees who wear religious clothing or symbols to work (as in the C. UK or the USA) are doing nothing more than making their cultural differences visible, and giving their workplace the same visible diversity as the street or public transport... And the religious clothing or symbols of employees do not affect the neutrality of their public sector employer, which in no way "endorses" their religions by permitting visible evidence of their affiliations in the workplace, any more than it 'endorses' any designer labels they wear. The secular character of public institutions is threatened only when the State itself endorses a particular religion... Secularism should not be interpreted as requiring employees to keep their religious affiliations invisible while at work, whether in the public or the private sector. Such an extreme interpretation of secularism permits the exclusion of religious individuals, unwilling to remove particular clotbing or symbols, from many opportunities in employment (Eweida and Dablab) or education (Leyla Sabin)» (R. WINTEMUTE, «Accommodating Religious Beliefs...», op. cit., p. 14). 
ción general que genere una discriminación directa o indirecta por razón de religión supone una agresión a la igualdad y a la libertad. Ahora bien, cada Estado gestiona de un modo distinto las diferencias culturales y religiosas (el modelo francés y anglosajón, por ejemplo, tienen un tratamiento legislativo diverso y España se sitúa en una posición intermedia).

Hay un consistente trabajo del Tribunal Europeo de Derechos Humanos sobre la libertad de religión en el ámbito del empleo y el deseo de los empresarios o empleadores para mantenerse seculares o neutrales ${ }^{51}$, aunque no resulta banal decidir sobre la acomodación de las creencias religiosas en el entorno laboral. No es lo mismo prohibir en un hospital cualquier símbolo religioso con el fin de impedir contagios ${ }^{52}$ que discernir sobre intereses más particulares y subjetivos del empresario en relación con su negocio, como utilizar una indumentaria que cubra casi toda la fisionomía en una relación laboral que exige el contacto, el trato y la comunicación, situación en la que se deben valorar otros aspectos.

Del mismo modo, la justicia europea irrumpía en el debate sobre el uso visible de cualquier signo político o religioso en el ámbito de las relaciones laborales abordando el debate sobre la prohibición del velo islámico en el marco laboral ${ }^{53}$. El Tribunal de Justicia de la Unión Europea (TJUE) entendió que impedir a una trabajadora utilizar esta prenda «no constituye una discriminación directa por motivos de religión o convicciones», avalando que las empresas puedan prohibir el uso de cualquier signo político o religioso en el lugar de trabajo. Nos referimos a la Sentencia TJUE (Gran Sala) de 14 de marzo de 2017, asunto C-157/15, caso Samira Achbita y Centrum voor gelijkheid van kansen en voor racismebestrijding G4S Secure Solutions $N V^{54}$.

El art. 1 de la Directiva 2000/7855 citada relativa al establecimiento de un marco general para la igualdad de trato en el empleo y la ocupación dis-

51 European Court of Human Rights, Research Division, «Overview of the Court's case-law on freedom of religion», documento emitido por el Consejo de Europa. Ver lo relativo al empleo, pp. 23-52, en https://www.echr.coe.int/Documents/Research_report_religion_ ENG.pdf (consultado el 10 de diciembre de 2019).

${ }_{52}$ Chaplin v. Royal Devon [2010] ET 1702886/2009 (24 de mayo de 2010) AT [20]; Eweida [2010] EWCA Civ 80 at [94].

53 Vid. sobre la materia J. García Murcia e I. A. Rodríguez Cardo, «Signos religiosos en la indumentaria de trabajo y principio de no discriminación: las primeras aportaciones del Tribunal de Justicia», Diario La Ley, núm. 9012 (2017).

54 Vid. Revista General de Derecho Canónico y Derecho Eclesiástico del Estado, núm. 44, (2017)

55 Directiva 2000/78/CE del Consejo, de 27 de noviembre de 2000, relativa al establecimiento de un marco general para la igualdad de trato en el empleo y la ocupación, dispo-

Foro, Nueva época, vol. 23, núm. 1 (2020): 155-220 
pone: «La presente Directiva tiene por objeto establecer un marco general para luchar contra la discriminación por motivos de religión o convicciones, de discapacidad, de edad o de orientación sexual en el ámbito del empleo y la ocupación, con el fin de que en los Estados miembros se aplique el principio de igualdad de trato».

El art. 2 de dicha Directiva establece que «se entenderá por principio de igualdad de trato la ausencia de toda discriminación directa o indirecta [...]. a) existirá discriminación directa cuando una persona sea, haya sido o pudiera ser tratada de manera menos favorable que otra en situación análoga $[\ldots] ; b)$ existirá discriminación indirecta cuando una disposición, criterio o práctica aparentemente neutros pueda ocasionar una desventaja particular a personas con una religión o convicción [...] determinadas, respecto de otras personas, salvo que: i) dicha disposición, criterio o práctica pueda justificarse objetivamente con una finalidad legítima y salvo que los medios para la consecución de esta finalidad sean adecuados y necesarios».

El núm. 18 de la Sentencia reza así: «En cuanto a la inexistencia de discriminación directa, este último órgano jurisdiccional destacó en concreto que era manifiesto que la Sra. Achbita no había sido despedida por profesar la fe musulmana, sino por persistir en su intención de hacerla patente durante las horas de trabajo llevando un pañuelo islámico. Según dicho órgano jurisdiccional, la norma del reglamento interno conculcada por la Sra. Achbita tiene un alcance general, puesto que prohíbe a cualquier trabajador llevar signos visibles de convicciones políticas, filosóficas o religiosas en el lugar de trabajo. Ningún hecho permite suponer que G4S haya adoptado una postura más conciliadora con algún otro asalariado en situación análoga, en particular con algún trabajador con otras convicciones religiosas o filosóficas que se hubiese negado repetidamente a respetar esa prohibición».

En su pronunciamiento final, y con respecto a la discriminación indirecta, se declara que tal norma interna de una empresa privada puede constituir una discriminación indirecta en el sentido del art. 2, apartado 2, letra b), de la Directiva 2000/78 si se acredita que la obligación aparentemente neutra que contiene ocasiona, de hecho, una desventaja particular a aquellas personas que profesan una religión o tienen unas convicciones determinadas, salvo que pueda justificarse objetivamente con una finalidad legítima, como el seguimiento por parte del empresario de un régimen

nible en https://www.boe.es/buscar/doc.php?id=DOUE-L-2000-82357 (consultado el 11 de febrero de 2020). 
de neutralidad política, filosófica y religiosa en las relaciones con sus clientes, y que los medios para la consecución de esta finalidad sean adecuados y necesarios; extremos que corresponderá comprobar al órgano jurisdiccional remitente.

Por tanto, se da autonomía y libertad al empresario para implantar un régimen de neutralidad política, filosófica y religiosa en las relaciones con sus clientes, siempre que los medios para la consecución de esta finalidad sean adecuados y necesarios.

En contrapartida, también se debe tener en cuenta la Sentencia del TJUE de 14 de marzo de 2017, asunto C-188/15, caso Asma Bougnaoui y Association de défense des droits de l'bomme (ADDH) contra Micropole SA, en la que se declara que la voluntad del empresario de tener en cuenta los deseos del cliente no constituye requisito profesional esencial y determinante para prohibir el uso del velo islámico a una trabajadora ${ }^{56}$.

No hay unanimidad de criterios en la jurisprudencia del TJUE, de modo que el club o el comité olímpico o paralímpico, según el caso, podría adoptar una actitud u otra, y luego vendrá el papel del poder judicial si aboca en un proceso, salvo utilización de medios alternativos de resolución.

Distinto es el supuesto de utilización de símbolos religiosos que comprometan la integridad física de aquellos que los portan, aunque sea en deporte de base en las escuelas ${ }^{57}$, aunque normalmente se prohíbe para no exhibir ideologías. Siguiendo a Minteguía Arregui ${ }^{58}$, en el caso del fútbol, en 2011 la Federación Internacional de Fútbol (FIFA) prohibió el uso de pañuelos islámicos a la selección femenina de Irán en los partidos de clasificación para los Juegos Olímpicos de Londres en 2012 por contener en sus reglamentos la mención a que el uniforme de ningún equipo puede contener un signo que pueda relacionarse con ideología o religión alguna ${ }^{59}$.

56 Vid. Revista General de Derecho Canónico y Derecho Eclesiástico del Estado, núm. 44, (2017).

57 Así lo mencionan B. Meseguer Velasco y S. Rodrigo Lara con referencia al Tribunal Europeo de Derechos Humanos en «La diversidad religiosa en la escuela: orientaciones jurídicas», Documentos del observatorio del pluralismo religioso en España, núm. 7 (2018), disponible en https://www.pluralismoyconvivencia.es/wp-content/uploads/2018/12/Doc.Obs_. 7-Diversidad-Religiosa-en-la-escuela.pdf (consultado el 3 de enero de 2020).

58 I. Minteguía ARREGUI, «Diversidad cultural y deporte profesional», op. cit., pp. 192-193.

${ }^{59}$ La regla 4 de las reglas del juego de la FIFA 2012-2013, sobre Equipamiento de los jugadores, al referirse a la seguridad: «Los jugadores no utilizarán ningún equipamiento ni llevarán ningún objeto que sea peligroso para ellos mismos o para los demás jugadores (incluido cualquier tipo de joyas)». Disponible en https://es.fifa.com/ $\mathrm{mm} /$ document/affede- 
Como algo novedoso, la Federación de Baloncesto (FIBA) levantó la prohibición de jugar con velo, turbante o kipá en $2017^{60}$ ante la demanda de un símbolo identitario.

Por el contrario, el uso de un símbolo religioso puede no ser un acto de libertad, sino de imposición que se levanta por conveniencias políticas (por ejemplo, en 2017 se publicó que en Arabia Saudí se permitía jugar en los mundiales de ajedrez sin velo, como una especie de gracia o concesión; en Irán, en contraste, se prohíbe a las gimnastas que se retiren el hiyab y tampoco pueden retirárselo para jugar al ajedrez).

\subsection{Prácticas religiosas que afectan al rendimiento}

Igualmente, el deporte impide ciertas prácticas como imperativos religiosos, como el ayuno en el Ramadán ${ }^{61}$, porque interfiere en su salud e integridad física. Durante este tiempo los fieles no deben comer ni beber desde el amanecer hasta el atardecer y deberían ajustar sus horarios de trabajo.

Con respecto a los futbolistas, los equipos deciden no presionar a sus futbolistas al considerar que el Ramadán es una decisión religiosa muy personal; sin embargo, los servicios médicos y los fisioterapeutas se muestran preocupados por su salud y el rendimiento para el resultado del partido. No inquieta tanto la falta de alimento como el hecho de no ingerir líquido. El músculo necesita estar hidratado; además, la caída en el nivel de azúcar en la sangre provoca debilidad y letargo.

Este es un modelo a seguir en el que se demuestra que la cooperación con el deporte y la cooperación con la libertad religiosa y la ideológica de

ration/generic/81/42/36/lawsofthegame_2011_12_es.pdf (consultado el 23 de diciembre de 2019). Un año más tarde, el International Football Association Board, organismo dependiente de la FIFA que tiene como función la aprobación de los reglamentos que rigen este deporte, autorizó en periodo de prueba el uso de pañuelos en la cabeza tras una reclamación realizada por las federaciones de países musulmanes y que contó con el apoyo de la propia ONU. Se llegó al acuerdo de utilizar velcro en los velos en los pañuelos para que no puedan desplazarse.

${ }^{60}$ Aunque se permite, no es un uso sin restricciones: «Recubrimiento para la cabeza. No cubrirá ninguna parte de la cara entera o parcialmente (ojos, nariz, labios, etc.) y no será peligroso para la persona que lo lleva y/o para otras personas. Tampoco puede contener elementos que se abran o cierren alrededor de la cara y/o cuello ni ninguna parte que presione desde su superficie» (reglas oficiales del baloncesto: https://www.clubdelarbitro.com/articulos/1789627.pdf (consultado el 4 de enero de 2020).

${ }^{61}$ El Acuerdo entre el Estado Español y la Comisión Islámica de España ha previsto este imperativo religioso en el art. 12. 
los deportistas no comprometen la neutralidad de Estado, salvo que se trate de afirmaciones (libertad de expresión), signos o símbolos que vayan en contra de la Constitución ${ }^{62}$.

\subsection{Derecho de libertad de expresión y sus límites ¿neutralidad o discriminación?}

Se podría contrarrestar esta postura con la necesidad de no influir sobre otras personas, incluso menores de edad, como es el caso de las mujeres musulmanas a quienes se les prohíbe usar el velo en establecimientos escolares debido a la vulnerabilidad de los niños y el posible adoctrinamiento. También los deportistas, debido a su influencia, pueden encontrarse en esta tesitura, que el derecho a ejercer su libertad de expresión en coherencia con su ideología o religión se traduzca en actos que tienen un gran peso sobre la sociedad.

Los futbolistas, por ejemplo, miembros del colectivo más numeroso y popular, al ser personajes muy conocidos y, por tanto, socialmente influyentes, cargan con una gran responsabilidad. El deportista de alto nivel se ha convertido en el modelo publicitario a seguir, ese con el que la juventud debe identificarse.

Algunas declaraciones no parecen ofender, como las de Joe Maloy, que en un mensaje de Facebook llegó a publicar que sus profesores, entrenadores y compañeros de clase le enseñaron lo que significaba la fe, trabajar por ideales y usarlo para hacer un mundo mejor. Podríamos seguir con innumerables ejemplos que han resultado inofensivos para la opinión públi$\mathrm{ca}$, sus patrocinadores o la neutralidad que supuestamente se exige en el deporte, como Kaká (futbolista), Kobe Bryant (jugador de baloncesto y recientemente fallecido), David Luiz (futbolista), Manny Pacquiao (boxea-

62 «Si el Estado coopera para que los españoles realicen actividades no religiosas - la ópera, el deporte, el cine, etcétera, incluso subvenciona a sindicatos y partidos políticosno por ello puede decirse que es confesionalmente operístico, deportivo o cinematográfico. Existe una cierta demanda social de promoción de esas actividades. Del mismo modo que no se causa agravio a quien le disgusta la ópera, por el hecho de que el Estado las subvencione, tampoco se causa agravio porque el Estado subvencione actividades religiosas que a algunos ciudadanos les parecen de interés, aunque a otros no les parezcan de interés o les desagraden. La Constitución establece esa cooperación como proporcional a la demanda social. Y no cabe desconocer que para muchos españoles practicar la religión es más importante que el apoyo que se pueda prestar al cine, o a la ópera o a los juegos florales» (J. M. González del Valle, Derecho Eclesiástico Español, Oviedo, Universidad de Oviedo, 1997, p. 145). 
dor), Vitor Belfort (luchador), Tim Tebow (jugador de futbol americano), Clint Dempsey (capitán de la selección norteamericana de futbol), Meseret Dejar (corredora etíope que llevó la imagen del niño Jesús durante todo el recorrido en 2012) y Lewis Hamilton (piloto de fórmula 1), entre otros.

\section{Discriminación de las libertades y derechos fundamentales en el ámbito laboral}

Cuando se impone una disposición, criterio o práctica en un sector profesional o en una empresa determinada (por ejemplo, una política sobre indumentaria que se aplica a todos sin excepción) no hay discriminación directa por razón de religión; sin embargo, indirectamente se está discriminando a un empleado $\mathrm{Sij}$ o a una musulmana que quiere portar un velo, por ejemplo.

La llave de esta situación está en determinar si esta discriminación directa o indirecta está justificada, por ejemplo, por seguridad o por razones de salud, algo parecido a las demandas fundamentadas en el art. 9 del Convenio Europeo de Derechos Humanos, sobre las que se puede resolver que existe una justificación para interferir en el ejercicio del derecho de libertad religiosa.

\subsection{Normativa española}

La Constitución española de 1978 otorga al Estado, de conformidad con su art. 149.1, competencias exclusivas en determinadas materias $^{63}$. Sobre esta base constitucional, el art. 14 de la Constitución consagra el principio de igualdad: «Los españoles son iguales ante la ley, sin que pueda prevalecer discriminación alguna por razón de nacimiento,

${ }^{63}$ La regulación de las condiciones básicas que garanticen la igualdad de todos los españoles en el ejercicio de los derechos y en el cumplimiento de los deberes constitucionales; la legislación laboral (párrafo 7. ${ }^{\circ}$ ), sin perjuicio de que corresponda a las Comunidades Autónomas su ejecución; el establecimiento de las bases y coordinación de la planificación general de la actividad económica (párrafo 13..$^{\circ}$ ) —en la medida que tal actividad incide o puede incidir en la configuración del mercado de trabajo en conexión con la anterior-; el establecimiento de las bases y la coordinación general de la sanidad y la legislación sobre productos farmacéuticos (párrafo 16. ${ }^{\circ}$ ); la legislación básica y régimen económico de la Seguridad Social (párrafo $17 .^{\circ}$ ), sin perjuicio igualmente de que la ejecución de la misma competa a las Comunidades Autónomas. 
raza, sexo, religión, opinión o cualquier condición o circunstancia personal o social».

El art. 14 encabeza el capítulo II de la Constitución dedicado a los derechos y libertades, y es susceptible, además, de amparo constitucional; de este modo, conforme a los arts. 161.b) y 53.2 de la Constitución, su presunta vulneración puede ser elevada, conforme a los requisitos legales establecidos en la Ley Orgánica del Tribunal Constitucional, ante esta instancia jurisdiccional.

Este principio de igualdad se ve reforzado en el ámbito laboral en el art. 35 de la Constitución, ya que se señala que todos los españoles tienen derecho al trabajo sin que quepa discriminación alguna por razón de sexo; como tal, el derecho al trabajo no es susceptible de amparo constitucional.

Si lo anterior resulta de aplicación, en general, en el conjunto del ordenamiento jurídico español, hay que tener presente la especificidad de base que resulta de las fuentes del Derecho laboral español y, en concreto, de la reglamentación de las relaciones laborales. Conforme al art. 37.1 de la Constitución, la ley debe garantizar «la fuerza vinculante de los convenios» fruto de la negociación colectiva. En este sentido, el art. 3.1 del Estatuto de los Trabajadores sitúa los convenios colectivos como fuente normativa aplicable a las relaciones laborales, por lo que deben ser considerados como un instrumento en manos de las partes sociales para implementar los preceptos normativos que pretenden poner en funcionamiento políticas específicas en el marco de las relaciones laborales.

Por otra parte, el propio art. 85.1 del Estatuto de los Trabajadores estipula que la autonomía contractual de unos convenios colectivos a los que se da eficacia jurídica erga omnes debe tener unos límites: debe situarse dentro del respeto a las leyes y, en todo caso, de lo que el art. 3 del Estatuto de los Trabajadores entiende como los mínimos derivados del derecho necesario. No puede haber duda alguna de que los convenios colectivos deben respetar, como sucede con otros derechos fundamentales, el art. 14 de la Constitución española —igualdad ante la ley y no discriminación-, así como el art. 4.2.c) del Estatuto de los Trabajadores en el que se establece el derecho básico de los/las trabajadores/as «a no ser discriminados directa o indirectamente para el empleo, o una vez empleados, por razones de sexo, estado civil, edad dentro de los límites marcados por esta Ley, origen racial o étnico, condición social, religión o convicciones, ideas políticas, orientación sexual, afiliación o no a un sindicato, así como por razón de lengua, dentro del Estado español». En consecuencia, no resultará conforme a Derecho una cláusula fruto de la negociación colectiva que, 
directa o indirectamente, comporte la introducción de una discriminación en las condiciones de remuneración, de acceso al empleo o de trabajo que se sustente en razón de los factores mencionados.

$\mathrm{El}$ art. 3.3 del Estatuto de los Trabajadores ${ }^{64}$ establece el principio pro operario que lleva a que, frente a conflictos existentes entre los preceptos de dos o más normas laborales, tanto estatales como pactadas, que deberán respetar en todo caso los mínimos de derecho necesario, se resolverán mediante la aplicación de lo más favorable para el trabajador apreciado en su conjunto, y en cómputo anual, respecto de los conceptos cuantificables.

En la normativa española encontramos leyes que definen los contornos de ambos tipos de discriminación, directa e indirecta. Así, la Ley Orgánica 3/2007, de 22 de marzo, para la igualdad efectiva de mujeres y hombres $^{65}$, en su art. 6 realiza las siguientes previsiones: «1) se considera discriminación directa por razón de sexo la situación en que se encuentra una persona que sea, haya sido o pudiera ser tratada, en atención a su sexo, de manera menos favorable que otra en situación comparable; 2) se considera discriminación indirecta por razón de sexo la situación en que una disposición, criterio o práctica aparentemente neutros pone a personas de un sexo en desventaja particular con respecto a personas del otro, salvo que dicha disposición, criterio o práctica puedan justificarse objetivamente en atención a una finalidad legítima y que los medios para alcanzar dicha finalidad sean necesarios y adecuados; 3) en cualquier caso, se considera discriminatoria toda orden de discriminar, directa o indirectamente, por razón de sexo».

En virtud de esta ley, se sanciona a El Corte Inglés como causante de una discriminación indirecta por razón de sexo en el sistema de promoción profesional en cuatro centros ubicados en Cataluña ${ }^{66}$. Se confirma la sentencia recurrida en casación que, tras un procedimiento iniciado de oficio, apreció la comisión de una infracción consistente en discriminación indirecta por razón de sexo en el sistema de promoción profesional de la empresa recurrente.

La ley de 2007 se ha modificado por el Real Decreto-ley 6/2019, de 1 de marzo, de medidas urgentes para garantía de la igualdad de trato y de

${ }^{64}$ Real Decreto Legislativo 2/2015, de 23 de octubre, por el que se aprueba el texto refundido de la Ley del Estatuto de los Trabajadores. BOE, núm. 255, de 24 de octubre de 2015 .

${ }_{65}$ BOE, núm. 71, de 23 de marzo de 2007. Referencia: BOE-A-2007-6115.

${ }^{66}$ Tribunal Supremo. Sala de lo Social. Sentencia de 18 de julio de 2011. Recurso de Casación núm. 133/2010. Ponente Excmo. Sr. José Manuel López García de la Serrana. 
oportunidades entre mujeres y hombres en el empleo y la ocupación ${ }^{67}$. La igualdad de trato y de oportunidades entre mujeres y hombres es un derecho básico de las personas trabajadoras. El derecho a la igualdad de trato entre mujeres y hombres debe suponer la ausencia de toda discriminación, directa o indirecta, por razón de sexo, y, especialmente, las derivadas de la maternidad, la asunción de obligaciones familiares y el estado civil. Este real decreto dispone el modo de implantar estas medidas según la capacidad de empleados de la empresa.

Como podemos constatar, en España la discriminación viene principalmente regulada de la mano de la igualdad por razón de sexo en el ámbito del empleo. Quizá por este motivo debemos atender a la normativa internacional y más concretamente la europea, que ofrece una perspectiva un poco más amplia dentro del ámbito laboral.

\subsection{Normativa internacional y europea. Su repercusión en España}

2.2.1. Definiciones y alcance general en la lucha contra la discriminación

Entre las normas internacionales de contenido laboral y con carácter internacional se encuentran los Convenios de la Organización Internacional del Trabajo (OIT) o la Carta Social Europea, elaborada en el seno del Consejo de Europa.

Las organizaciones internacionales pueden dictar también actos normativos externos dirigidos a sus Estados miembros que, sin ser obligatorios jurídicamente, pretenden condicionar o dirigir la conducta estatal y, por tanto, tienen carácter esencialmente programático: las denominadas recomendaciones intersubjetivas (por ejemplo, las Resoluciones de la Asamblea General de las Naciones Unidas). Su falta de obligatoriedad hace, en principio, ociosa la necesidad de su incorporación al ordenamiento jurídico español.

Con respecto al Derecho comunitario europeo, hay que partir de la idea de que, conforme a los Tratados Constitutivos de las Comunidades Europeas, los Estados miembros de las mismas y de la Unión Europea realizan la cesión del ejercicio de competencias soberanas, incluidas las competencias de naturaleza normativa, en favor de las instituciones comuni-

${ }^{67}$ BOE, núm. 57, de 7 de marzo de 2019. Referencia: BOE-A-2019-3244. 
tarias, que permitirán a estas legislar en aquellos ámbitos en que se haya producido tal cesión competencial. Esta cesión fue autorizada en lo que concierne a España mediante ley orgánica conforme al art. 93 de la Constitución española.

De conformidad con el art. 13 del Tratado de la Comunidad Europea, con carácter supletorio respecto de las bases jurídicas que acabamos de ver, esta disposición introducida también mediante el Tratado de Ámsterdam permite al Consejo adoptar acciones adecuadas para luchar contra la discriminación por motivos de sexo, de origen racial o étnico, religión o convicciones, discapacidad, edad u orientación sexual.

El Consejo ha adoptado varias directivas sobre la base del art. 13 TCE, de las cuales interesa aquí destacar dos: la Directiva 2000/43/CE, de 29 de junio de 2000, relativa a la aplicación del principio de igualdad de trato de las personas, independientemente de su origen racial o étnico, y la Directiva 2000/78/CE, de 27 de noviembre de 2000, relativa al establecimiento de un marco general para la igualdad de trato en el empleo y la ocupación, que ya hemos citado anteriormente en este trabajo.

La OIT es una organización internacional creada en 1919 de carácter universal cuyos fines se ubican precisamente en el ámbito sociolaboral. Conforme a la Constitución de la OIT y la Declaración de la OIT relativa a los Principios y Derechos Fundamentales en el Trabajo, de 19 de junio de 1998, la eliminación de la discriminación en materia de empleo y ocupación se enmarca como uno de los cuatro derechos sociolaborales fundamentales.

El Convenio 168 sobre el fomento del empleo y la protección contra el desempleo de 1988 establece en su art. 6 una protección en tales ámbitos, sin discriminación alguna por motivos de raza, color, sexo, religión, opinión política, ascendencia nacional, nacionalidad, origen étnico o social, invalidez o edad; si bien se prevé la posibilidad de adoptar medidas especiales justificadas por las necesidades específicas de categorías de personas que encuentran problemas particulares en el mercado del trabajo.

Asimismo, las discriminaciones retributivas son subsumibles en la conducta infractora muy grave recogida en el núm. 12 del art. 8 de la ya mencionada Ley de Infracciones y Sanciones del Orden Social: «Las decisiones unilaterales del empresario que impliquen discriminaciones directas o indirectas desfavorables por razón de edad o discapacidad o favorables o adversas en materia de retribuciones, jornadas, formación, promoción y demás condiciones de trabajo, por circunstancias de sexo, origen, inclui- 
do el racial o étnico, estado civil, condición social, religión o convicciones, ideas políticas, orientación sexual».

Hay al menos cuatro formas en las que un reclamo de acomodación de las creencias religiosas podrían presentarse bajo el CEDH, las dos primeras involucran «libertad»y los dos últimas implican «igualdad» ${ }^{68}$ :

1) Una interferencia activa con una manifestación particular de las creencias religiosas de un individuo, incumpliendo la obligación negativa del Estado del art. 9 de respetar la libertad de religión.

2) La actitud pasiva para acomodar una manifestación particular de las creencias de un individuo, violando la obligación positiva del art. 9, según la cual el Estado debe respetar la libertad de religión.

3) Discriminación directa (contrario al art. 14 combinado con el art. 9) contra un individuo denegando la acomodación de su manifestación particular de creencias religiosas, en comparación con el trato que se ofrece a un individuo que profesa otra religión a quien sí se concedió una acomodación de sus creencias.

4) Discriminación indirecta (contrario al art. 14 combinado con el art. 9 u otro Derecho ECH1) contra un individuo denegando la acomodación de sus creencias religiosas, al aplicar una regla neutral, que ha tenido un desproporcionado impacto sobre esa persona o un grupo minoritario.

Estrictamente hablando, solo las formas segunda y cuarta implican acomodación, en el sentido estricto de una exención especial de las reglas neutrales que no se extiende a otros. Sin embargo, para proporcionar una imagen completa, las formas primera y tercera deben estudiarse, porque la no acomodación a veces se caracteriza por el TEDH como interferencia con la libertad de religión, y tampoco se sostiene la acomodación de algunas pero no de todas las religiones.

Las normativas de la UE y el CEDH están actualmente estrechamente vinculadas. Todos los Estados miembros de la Unión se han incorporado al Convenio y, como ya se ha indicado, el TJUE se inspira en el CEDH para determinar el alcance de la protección de derechos humanos con arreglo a la normativa de la Unión. La Carta de Derechos Fundamentales refleja también la gama de derechos del Convenio (aunque no se limita a ellos). Por tanto, aunque la UE no es propiamente miembro del CEDH, su normativa se ajusta en gran medida al Convenio. No obstante, si una perso-

${ }^{68}$ R. Wintemute, «Accommodating Religious Beliefs...», op. cit., p. 4. 
na desea formular una reclamación en materia de incumplimiento de los derechos humanos por parte de la UE, no puede llevarla ante el TEDH, sino que debe optar entre acudir a los tribunales nacionales, que podrán remitir posteriormente el caso al TJUE a través del procedimiento de cuestión prejudicial, o reclamar indirectamente contra la UE ante el TEDH, demandando a un Estado miembro.

La normativa contra la discriminación establece que las personas que se hallan en situaciones diferentes deben recibir un trato diferente, en la medida necesaria para que puedan disfrutar de oportunidades concretas del mismo modo que los demás. Por tanto, estos mismos motivos protegidos deben tenerse en cuenta al realizar determinadas prácticas o crear normas concretas. Esto es lo que se conoce como discriminación indirecta. Todas las formas de discriminación indirecta están sujetas a una causa de justificación objetiva, con independencia de que la reclamación se realice al amparo del CEDH o de la legislación de la UE.

Podemos describir de modo más detallado la discriminación directa siguiendo el Manual de Legislación Europea contra la Discriminación ${ }^{69}$, que en el capítulo 5 analiza los distintos motivos protegidos existentes en la legislación europea contra la discriminación: el género, la orientación sexual, la discapacidad, la edad, la raza, el origen étnico y nacional, la religión y las creencias $^{70}$. En este apartado se analiza la necesidad de un nexo causal entre el trato menos favorable y el motivo protegido. Para cumplir este requisito basta formular una sencilla pregunta: ¿hubiera recibido la persona un trato menos favorable si hubiera tenido distinto género, raza o edad o hubiera ocupado otra posición en alguno de los restantes motivos protegidos? Si la respuesta es afirmativa, el trato menos favorable se debe claramente al motivo en cuestión.

La disposición o práctica aplicada no ha de hacer necesariamente referencia explícita al motivo protegido, siempre que mencione otro factor indisociable de este ${ }^{71}$.

${ }^{69}$ bttps://fra.europa.eu/sites/default/files/fra_uploads/fra-2018-handbook-non-discrimination-law-2018_es.pdf (consultado el 11 de agosto de 2020).

70 Ya en el Tratado de Amsterdam de 1997 se introdujeron estos motivos, ampliando la simple discriminación por razón de sexo.

${ }^{71}$ Se han juzgado casos interesantes como apreciar la discriminación de los hijos, en virtud de la situación de discriminación de sus padres. Un ejemplo de esto se vio en el asunto Weller contra Hungría en el que una mujer rumana estaba casada con un húngaro, con quien había tenido cuatro hijos, pero no tenía derecho a la prestación de maternidad por nacimiento por no ser de nacionalidad húngara. Su marido trató de reclamar la prestación, que le fue denegada porque solo tenían derecho a percibirla las madres. El TEDH consideró 
2.2.2. Estudio de la discriminación y las manifestaciones religiosas en el ámbito laboral y su aplicación al deporte profesional. Especial referencia a la discriminación indirecta

\section{a) Definición y contexto general}

Tanto la normativa de la UE como el CEDH reconocen que la discriminación puede existir no solo cuando se trata de modo diferente a personas en situaciones similares, sino también cuando se trata de forma idéntica a personas en situaciones diferentes. Esta última forma de discriminación se denomina indirecta porque no es el trato lo que difiere, sino sus efectos, que afectan de distinto modo a personas con características diferentes.

$\mathrm{El}$ art. 2.2).b) de la Directiva relativa a la igualdad racial establece que «existirá discriminación indirecta cuando una disposición, criterio o práctica aparentemente neutros sitúe a personas de un origen racial o étnico concreto en desventaja particular con respecto a otras personas». El TEDH se ha basado en esta definición de la discriminación indirecta en algunos de sus últimos fallos, señalando que «la diferencia de trato puede consistir en unos efectos desproporcionadamente perjudiciales de una política o medida general que, pese a estar formulada de modo neutro, discrimine a un determinado grupo».

El primer elemento identificable es una disposición, criterio o práctica aparentemente neutros. En otras palabras, debe haber algún tipo de requisito aplicable a todas las personas. Un ejemplo clarificador lo tenemos en el asunto D. H. y otros contra la República Checa ${ }^{72}$ en el que se empleaban una serie de pruebas para determinar la inteligencia y la idoneidad de los alumnos con el fin de decidir si debían ser apartados de la educación general y adscritos a escuelas especiales, diseñadas para personas con discapacidades intelectuales u otras dificultades de aprendizaje. Aunque se aplicó la misma prueba a todos los alumnos considerados susceptibles de adscripción a las escuelas especiales, en realidad había sido diseñada basán-

que el marido había sido objeto de discriminación por razón de paternidad (no de género), pues los padres y los tutores adoptivos varones tenían derecho a la prestación, excluida para los padres biológicos. También se presentó una reclamación en nombre de los hijos, alegando discriminación por la denegación de la prestación a su padre, la cual fue también admitida por el TEDH, apreciando una discriminación por razón de la situación de su padre como padre biológico. Cfr. TEDH, Weller contra Hungría (núm. 44399/05), 31 de marzo de 2009.

${ }_{72}$ TEDH, D. H. y otros contra la República Checa [GC] (núm. 57325/00), 13 de noviembre de 2007 , párr. $184.1+$. 
dose en la población general checa, de modo que los estudiantes gitanos tenían intrínsecamente mayor probabilidad de obtener malos resultados, como efectivamente ocurrió, con la consecuencia de que entre el 80 y el 90 por 100 de ellos se educaron fuera del sistema educativo general. El TEDH consideró que se trataba de un caso de discriminación indirecta ${ }^{73}$.

\section{b) Los derechos humanos y las leyes antidiscriminatorias}

El enfoque de la Unión Europea con las leyes antidiscriminatorias tiene un foco inicial de exigencias económicas y de competición justa hacia el reconocimiento de la necesidad de prevenir la discriminación como una cuestión de justicia social. El desarrollo de los estándares de derechos humanos dentro del marco de la Convención Europea ha priorizado siempre la promoción de la dignidad ${ }^{74}$.

Al igual que la Directiva de empleo, también en el año 2000 se adoptó la Carta de Derechos Fundamentales y como lo hace el Convenio de Derechos humanos, en su capítulo II, se reconocen las libertades como la libertad de pensamiento, de conciencia, de religión ${ }^{75}$, de expresión, pero también y de modo específico la libertad de elegir un ocupación y de comprometerse con un empleo.

Ahora bien, aunque haya expresa referencia al empleo en el Convenio de Derechos humanos, el art. 9 ha sido el fundamento de las demandas de trabajadores. Así lo vemos en $A b m a d v$. $U K^{76}$, en el que un profesor de colegio musulmán exige que se le permita no trabajar el viernes por la tarde con el fin de orar; Stedman v.U.K ${ }^{77}$, en la que un trabajador cristiano

73 E. Dubout, «L'interdiction des discriminations indirectes par la Cour européenne des droits de l'homme: rénovation ou révolution? Epilogue dans l'affaire D. H. et autres c. République tchèque, Cour européenne des droits de l'homme (Grande Chambre), 13 novembre 2007», Revue trimestrielle des droits de l'bomme, vol. 75 (2008).

74 Vid. en este sentido O. HAZEL, «Anti-discrimination and Human Rights Standards in Europe: Lessons for the European Model», Canadian Labor E Employment Law Journal, vol. 14 (2008), p. 194.

75 Tanto el Convenio como la Carta y las Directivas no ofrecen un concepto claro de religión, y así se ha permanecido a la espera de la jurisprudencia que tiene un reto por la limitación de la neutralidad. Con esta laguna no solo se utiliza la expresión religión sino creencia. Los Estados miembros difieren, en algunos países las creencias engloban las convicciones filosóficas, o se refieren simplemente a la libertad de pensamiento en general.

${ }^{76}$ Abmad v. UK (1982) 4 EHRR 126, disponible en http://budoc.echr.coe.int/engpress? $i=003-3191940-3556501$ (consultado el 1 de septiembre de 2020).

77 Stedman v. United Kingdom (1997) 23 EHRR CD 168, disponible en bttp://budoc. echr.coe.int/fre? $i=001-3620$ (consultado el 1 de septiembre de 2020). 
no deseaba trabajar en domingo; y Konttinen $v$. Finland ${ }^{78}$, en la que un trabajador perteneciente a la Iglesia Adventista del séptimo día solicita tener el libre el viernes desde la puesta de sol.

Sin embargo, los derechos humanos están comprometidos cuando la organización empresarial tiene un determinado ideario. Así, por ejemplo, si se expresan ideas contrarias a las que identifican a un centro escolar privado y religioso, o se usa una indumentaria prohibida por motivos religiosos o por compromiso con la neutralidad, basándose en el ethos de la empresa.

La Directiva 2000/78/EC transige a los Estados miembros permitir que las organizaciones religiosas establezcan requisitos profesionales genuinos, legítimos y justificados que sean discriminatorios por razón de religión en dos situaciones: la religión de una persona es requerida por la naturaleza de sus actividades; la religión de una persona es requerida por el contexto en el que realiza sus actividades. En otras palabras, el art. 4, apartado 2, de la Directiva 2000/78 / CE permite a los Estados miembros que su legislación nacional incorpore prácticas nacionales conforme a las cuales, en el caso de actividades ocupacionales dentro de iglesias y otros u organizaciones privadas, existan diferencias de trato basadas en la religión o creencia sin constituir discriminación, siempre que la religión o las creencias de una persona constituyen una auténtico, legítimo y justificado requisito ocupacional teniendo en cuenta la naturaleza de las actividades, y el contexto en el que se llevan a cabo, así como el espíritu de la Organización.

Pensando en los clubes deportivos españoles como asociaciones de naturaleza privada con un estatuto propio aunque con carácter mercantil, podríamos encontrarnos con este tipo de alegaciones, el ethos del club, o la naturaleza de sus actividades, así como su contexto. Lo cierto es que con carácter mercantil o no, carecen de ideario propio, salvo los clubes de organizaciones religiosas o las asociaciones deportivas mixtas.

La licencia de las organizaciones privadas o públicas con ideario propio no la tienen los contratos privados de personas físicas, en los que no se justifica la discriminación directa ni indirecta, ni lesión alguna de los derechos fundamentales, así el United Kingdom Employment Tribunal, en su decisión Turkey v. Chandhok \& Anor ${ }^{79}$. Una mujer india, pobre, y de casta baja fue

78 (1996), 8 Eur. Comm'n H.R.D.R. 68, disponible en bttp://budoc.echr.coe.int/ fre? $i=001-3379$ (consultado el 6 de julio de 2020).

79 UKET 3400174/2013, 13 de septiembre de 2015. Vid. su comentario: «Elimination of Discrimination at the Workplace», International Labor Rights Case Law International BRILL vol. 2 (2016), pp. 63-69. 
contratada por un matrimonio formado por una mujer india nacida en Bretaña, y un marido hindú nacido en Afganistán. La mujer no solo fue explotada laboralmente, sino que con el fin de impedir que tuviera otras distracciones, y mantener un régimen de control sobre ella, restringían sus movimientos, le impedían que practicara sus creencias y atendiera a servicios religiosos, tampoco le permitían que tuviera textos religiosos ni una cruz cristiana. El tribunal admitió que hubo discriminación indirecta por motivos religiosos.

c) Consecuencias penales en caso de discriminación por razón de religión y los actos que incitan a la violencia, al acoso y al odio

Aunque las directivas contra la discriminación no obligan a los Estados miembros a utilizar el Derecho penal para sancionar los actos de discriminación, una Decisión Marco del Consejo Europeo obliga a todos los Estados miembros a establecer sanciones penales por la incitación a la violencia o el odio por razones de raza, color, ascendencia, religión o creencias, origen nacional o étnico, así como por la divulgación de materiales racistas o xenófobos y por la apología, la negación y la trivialización de actos de genocidio, crímenes de guerra y crímenes contra la humanidad dirigidos contra estos grupos ${ }^{80}$.

En el ámbito del deporte puede que no haya violencia por parte del empleador, pero sí de los aficionados o de los compañeros deportistas. Igualmente, podemos encontrarnos con la incitación al odio, y la provocación del acoso por razón de religión, u otros motivos. Aunque el CEDH no prohíbe específicamente el acoso y las órdenes de discriminar, recoge ciertos derechos en este campo. De este modo, el acoso puede caer en el ámbito del derecho al respeto a la vida privada y familiar, protegido en el art. 8 del CEDH, o el derecho a no ser sometido a penas o tratos inhumanos o degradantes del art. 3, mientras que las órdenes de discriminar pueden caer en el ámbito de otros artículos, como la libertad de religión y de reunión y asociación de los arts. 9 y 11, dependiendo del contexto. Si estos actos constituyen un motivo de discriminación, el TEDH analizará los supuestos incumplimientos de estos artículos, en relación con el art. 14, que prohíbe la discriminación.

${ }^{80}$ Decisión Marco 2008/913/JAI del Consejo, de 28 de noviembre de 2008, relativa a la lucha contra determinadas formas y manifestaciones de racismo y xenofobia mediante el Derecho penal, DO, núm. L 328, 6 de diciembre de 2008, p. 55. 
En España, la aprobación de la Ley 51/2003, de 2 de diciembre, sobre igualdad de oportunidades, no discriminación y acceso universal de las personas con discapacidad ${ }^{81}$, y la Ley 62/2003, de 30 de diciembre, sobre Medidas fiscales, administrativas y del orden social ${ }^{82}$, supusieron un avance considerable en la clarificación del concepto de acoso discriminatorio desde una perspectiva jurídica, si bien la respuesta legal ha resultado en general insuficiente como consecuencia del punto de vista del que se ha abordado el fenómeno: la igualdad de trato y no discriminación en numerus clausus. En ambos casos se aborda la cuestión únicamente desde la perspectiva de la lucha contra la discriminación por razón de origen racial o étnico, religión o convicciones, discapacidad, edad u orientación sexual. La Ley 62/2003 retoma y retoca escasamente la definición de acoso avanzada por la Ley 51/2003. Así, el art. 28.1.d) de la Ley 62/2003 define el acoso como: «toda conducta no deseada relacionada con el origen racial o étnico, la religión o convicciones, la discapacidad, la edad o la orientación sexual de una persona, que tenga como objetivo o consecuencia atentar contra su dignidad y crear un entorno intimidatorio, humillante $\mathrm{u}$ ofensivo».

Hay que destacar por lo que concierne al Estatuto de los Trabajadores la nueva redacción que se da al párrafo e) del apartado 2 del art. 4: los trabajadores tienen derecho al «respeto de su intimidad y a la consideración debida a su dignidad, comprendida la protección frente a ofensas verbales y físicas de naturaleza sexual y frente al acoso por razón de origen racial o étnico, religión o convicciones, discapacidad, edad u orientación sexual». La novedad reside aquí, en la introducción por vez primera en nuestra legislación del concepto de acoso como nueva forma de discriminación, frente a la que cabe la tutela jurídica del derecho del trabajador o trabajadora con todos los instrumentos predispuestos en nuestro ordenamiento a favor del derecho fundamental a la igualdad de trato y no discriminación cuando estamos ante personas que resultan más vulnerables a tenor de los análisis realizados sobre la realidad social: las personas en riesgo de exclusión social, las personas vulnerables por razón de origen racial o étnico, religión o convicciones, discapacidad, edad u orientación sexual, y, desde una perspectiva más específica, algunos colectivos sociales como los inmigrantes, los discapacitados y las víctimas de la violencia de género.

${ }^{81}$ BOE, núm. 289, de 3 de diciembre de 2003, disponible en https://www.boe.es/eli/ es/l/2003/12/02/51/con (consultado el 17 de julio de 2020).

82 BOE, núm. 313, de 31 de diciembre de 2003, disponible en https://www.boe.es/eli/ es/l/2003/12/30/62/con (consultado el 17 de julio de 2020). 
El mercado de trabajo en el deporte profesional no es ajeno a los estereotipos sociales, de manera que la integración laboral de las personas incluidas dentro de estos colectivos vulnerables por razón de religión o convicciones no es siempre sencilla, ya que la impresión negativa puede provenir no solo del empresario, sino también de los trabajadores y, en el caso de los servicios, de los propios usuarios. Además, las prácticas discriminatorias pueden ser sutiles, casi imperceptibles, y, sobre todo, difíciles de demostrar pues, aun cuando en los procesos judiciales pueda alterarse el sentido de la carga de la prueba, tampoco resulta imposible para el empleador argumentar que las decisiones adoptadas lo son a título objetivo o a resultas del comportamiento individual del trabajador pese a que tras ellas puedan encubrirse tratos discriminatorios.

\section{d) Justificación de la discriminación}

La igualdad, como señala García Murcia, es la base del sistema y «puede convivir con aquellas diferencias de trato que cuenten con alguna justificación aceptable, pero no puede tolerar determinadas distinciones, que se entienden discriminatorias no ya porque separan o dividen, sino porque generan situaciones de inferioridad o indignidad para las personas o grupos sociales afectados» ${ }^{83}$.

Si estamos ante personas y situaciones similares, de acuerdo con el TEDH: «La diferencia de trato a personas en situaciones sustancialmente similares [...] es discriminatoria si no tiene una justificación objetiva y razonable; en otras palabras, si no persigue un fin legítimo o no hay una relación de proporcionalidad razonable entre los medios empleados y el fin perseguido» ${ }^{84}$.

Para el TJUE, la exigencia de que las medidas adoptadas sean «necesarias» implica que debe acreditarse la inexistencia de otros medios razonables que pudieran causar menores interferencias con el principio de igualdad de trato ${ }^{85}$.

83 J. García Murcia, «Igualdad y no discriminación en las relaciones laborales», en M. E. Casas BaAmonde, F. DuRán López y J. Cruz Villalón (coords.), Las transformaciones del Derecho del Trabajo en el marco de la Constitución española. Estudios en Homenaje al Profesor Miguel Rodríguez-Piñero y Bravo-Ferrer, Madrid, La Ley, 2006, p. 394.

84 TEDH, Burden contra el Reino Unido [GC] (núm. 13378/05), 29 de abril de 2008, párr. 60.

${ }^{85}$ Bilka-Kaufhaus GmbH contra Weber Von Hartz, TJUE Bilka-Kaufhaus GmbH contra Weber Von Hartz, Asunto 170/84 [1986] Rec. 1607, 13 de mayo de 1986. 
En el ámbito laboral, la causa de justificación de los requisitos profesionales esenciales aparece en todas las directivas (excepto en la Directiva de igualdad de trato entre hombres y mujeres en el acceso a los bienes y servicios, que no hace referencia al empleo) y permite a los empleadores diferenciar entre las personas por motivos protegidos cuando estos tienen relación intrínseca con la capacidad de desempeñar un determinado trabajo o las cualificaciones necesarias para el mismo.

Otras causas de justificación aparecen en la Directiva Europea de igualdad de trato en el empleo y la ocupación ${ }^{86}$. En primer lugar, y la que más nos interesa es la admisibilidad de la discriminación por religión o creencias por parte de los empleadores que sean organizaciones basadas en la religión o las convicciones ${ }^{87}$. En segundo lugar, la admisibilidad de la discriminación por edad en ciertas circunstancias. El planteamiento estricto del TJUE sobre la interpretación de las causas de justificación del trato diferente indica que las posibles excepciones se interpretarán de forma restrictiva, en la medida que resalta la importancia de los derechos reconocidos a las personas en la legislación de la UE ${ }^{88}$.

La Directiva 2000/78, no trata de tutelar el ejercicio del derecho fundamental de libertad religiosa de forma directa ${ }^{89}$. Ni tampoco se trata de un texto que regule de forma autónoma este derecho fundamental dentro del ordenamiento comunitario más allá de su posible consideración como un principio general que ha de ser objeto de protección por los Tribunales de Justicia. Simplemente lo que esta Directiva plantea es una tutela adicional de este derecho fundamental. En su construcción general, en los conceptos que se definen en la misma y en la regulación de los mecanismos de reacción frente a la discriminación, la totalidad de la Directiva es deudora de la ya consolidada construcción comunitaria acerca de la discriminación

${ }^{86}$ Directiva 2000/78/CE del Consejo, 27 de noviembre de 2000, relativa al establecimiento de un marco general para la igualdad de trato en el empleo y la ocupación, disponible en https://eur-lex.europa.eu/legal-content/ES/TXT/?uri=LEGISSUM\%3Ac10823 (consultado el 10 de agosto de 2020). La Directiva establece un marco general para garantizar la igualdad de trato en el lugar de trabajo de las personas de la Unión Europea (UE), independientemente de su religión o convicciones, discapacidad, edad u orientación sexual.

${ }_{87}$ Art. 4.2 de la Directiva 2000/78/CE del Consejo, de 27 de noviembre de 2000, relativa al establecimiento de un marco general para la igualdad de trato en el empleo y la ocupación, disponible en https://eur-lex.europa.eu/LexUriServ/LexUriServ.do?uri=OJ:L:2000:303: 0016:0022:ES:PDF (consultado el 4 de abril de 2020).

${ }^{88}$ Vid., por ejemplo, TJUE, Johnston contra Chief Constable of the Royal Ulster Constabulary, Asunto 222/84 [1986] Rec. 1651, 15 de mayo de 1986, párr. 36.

${ }^{89}$ Vid. J. Rosell Granados, La no discriminación por motivos religiosos en España, Madrid, Ministerio de Trabajo y Asuntos Sociales, 2008, pp. 64-65. 
por razón de género. Así esta influencia se observa en el art. 2 y la definición de los conceptos de discriminación directa, la discriminación indirecta, y la introducción del concepto de acoso por motivos religiosos ${ }^{90}$, y de la misma forma, en el art. 10, al trasladar la carga de la prueba al demandado siempre y cuando la parte demandante pruebe que pertenece a una determinada religión o que tiene una determinada convicción.

En el caso de los deportistas, no estamos ante organizaciones empresariales basadas en la religión o creencias. Ahora bien, en un estudio general de las directivas, hay otra causa de justificación que permite a los empleadores diferenciar entre personas por una característica directamente relacionada con la idoneidad o capacidad para desempeñar las funciones de un determinado puesto. Hay trabajos ya claramente incluidos en la excepción de los requisitos profesionales esenciales. En el asunto de la Comisión contra Alemania, el TJUE ${ }^{91}$, señaló ciertas profesiones en las que la causa de justificación podía probablemente aplicarse, prestando especial atención a las profesiones artísticas que pueden requerir características especiales inherentes a las personas, como las que precisa una cantante para encajar con un determinado estilo de actuación, un joven actor para representar un papel, una persona con cualidades físicas para bailar o los hombres y las mujeres para actuar como modelos de moda, aunque sin tratar de establecer una lista exhaustiva.

Pues bien, no se puede seleccionar a un deportista para la elite profesional, únicamente si no expresa o manifiesta sus creencias a través de la libertad de expresión, de signos o de símbolos, o de una indumentaria determinada. Quienes llegan a ser profesionales, es porque son idóneos para su trabajo, ya se habrá demostrado que no ponen en peligro su integridad física, y que no pretenden practicar el proselitismo, salvo que la conversión de fe sea sobrevenida.

90 Art. 2.3: «El acoso constituirá discriminación a efectos de lo dispuesto en el apartado 1 cuando se produzca un comportamiento no deseado relacionado con alguno de los motivos indicados en el art. 1 que tenga como objetivo o consecuencia atentar contra la dignidad de la persona y crear un entorno intimidatorio, hostil, degradante, humillante u ofensivo. A este respecto, podrá definirse el concepto de acoso de conformidad con las normativas y prácticas nacionales de cada Estado miembro».

${ }_{91}$ 61983J0248. Judgment of the Court of 21 May 1985 - Commission of the European Communities $v$ Federal Republic of Germany - Equal treatment for men and women - Case 248/83, disponible en bttps:/leur-lex.europa.eu/legal-content/EN/TXT/HTM L/?isOldUri=trueEuri=CELEX:61983CJ0248, consultada el 12 de agosto de 2020. 


\section{e) Medidas especiales para corregir la desigualdad}

Como se ha señalado anteriormente, en los casos de discriminación indirecta, el motivo por el que se aprecia la discriminación es la aplicación de la misma disposición a todas las personas sin tener en cuenta las diferencias sustanciales. Para corregir y evitar este tipo de situaciones, los gobiernos, los empleadores y los prestadores de servicios deben asegurarse de adoptar medidas para ajustar sus disposiciones y prácticas con el fin de tener en cuenta estas diferencias; es decir, deben hacer algo para adaptar sus políticas y medidas vigentes. En el ámbito de la ONU, se denominan medidas especiales ${ }^{92}$, mientras que en el derecho de la UE se habla de medidas específicas o de acción positiva ${ }^{93}$. Con estas medidas especiales, los gobiernos pueden asegurar la igualdad sustantiva (art. 9.2 de la Constitución española), es decir, la igualdad en el disfrute de las oportunidades de acceder a los beneficios disponibles en la sociedad, en lugar de la mera igualdad formal. Si los gobiernos, los empleadores y los prestadores de servicios no tienen en cuenta la pertinencia de adoptar medidas especiales, aumentan el riesgo de que incurrir en disposiciones y prácticas constitutivas de discriminación indirecta.

Al igual que la prohibición de realizar gestos o signos de carácter religioso a un deportista puede suponer una discriminación indirecta en virtud de la neutralidad en el deporte, de su limpieza de virus religiosos o políticos

92 Recomendación general núm. 25, sobre el párrafo 1 del art. 4 de la Convención sobre la eliminación de todas las formas de discriminación contra la mujer, referente a medidas especiales de carácter temporal, disponible en https://www.unwomen.org/es/how-wework/gender-parity-in-the-united-nations/strategies-and-tools (consultado el 8 de agosto de 2020); Recomendación general núm. 32, Significado y alcance de las medidas especiales en la Convención Internacional sobre la Eliminación de todas las Formas de Discriminación Racial, CERD/C/GC/32, disponible en https://www.acnur.org/fileadmin/Documentos/ BDL/2012/8464.pdf (consultado el 8 de agosto de 2020).

${ }^{93}$ El Consejo de Europa describe las acciones afirmativas como los casos en los que se puede aplicar un tratamiento preferencial o positivo hacia las personas que pertenecen a ciertos grupos como intento de atenuar o reparar los perjuicios causados por la discriminación estructural (https://www.coe.int/es/web/compass/discrimination-and-intolerance). En general, se trata de medidas dirigidas a eliminar las desigualdades existentes contra grupos históricamente discriminados. Las medidas específicas son temporales y con ellas se pretende suprimir y compensar las desventajas existentes. El Consejo de las Comunidades Europeas recomienda a los Estados miembros que adopten políticas de acción positiva para eliminar las desigualdades que de hecho sufren las mujeres en su vida profesional y conseguir una participación equilibrada en las profesiones y niveles jerárquicos. Estas medidas específicas en favor de las mujeres se prevén en la Ley Orgánica 3/2007, de 22 de marzo, para la igualdad efectiva de mujeres y hombres. En BOE, núm. 71, de 23 de marzo de 2007 (BOE-A-2007-6115). 
que hagan tambalear la seguridad pública, también se aprecia dicha discriminación en el asunto Thlimmenos contra Grecia ${ }^{94}$. La legislación nacional prohibía a los condenados por delitos ejercer la profesión de censor jurado de cuentas, porque el delito implica una falta de la honradez y la fiabilidad necesarias para desempeñar estas funciones, medida que parece neutral y razonable. En este asunto, el reclamante había sido condenado penalmente por negarse a prestar el servicio militar obligatorio debido a que era miembro del grupo religioso pacifista de los Testigos de Jehová. El TEDH consideró que no había motivos para excluir del ejercicio de la profesión a personas condenadas por delitos no relacionados con la fiabilidad o la honradez. El gobierno había discriminado al solicitante al no incluir una excepción a la regla general para estos casos, vulnerando el derecho a la manifestación de las creencias religiosas (conforme al art. 9 del CEDH), en relación con la prohibición de la discriminación.

Haciendo un símil con el supuesto que nos ocupa, acogotar la libertad de expresión y la libertad de actuar conforme a las creencias religiosas no es el método más idóneo para evitar actos de odio, violencia o de acoso. Que los clubes u otras altas instancias del deporte prohíban el ejercicio de los derechos humanos de las personas deportistas para evitar que otros, aficionados o deportistas, violen los derechos humanos de los deportistas es un contrasentido, no es una buena lección de juego limpio en el deporte, en todo caso, un modo de lavarse las manos creando un espacio aséptico.

Lo mismo se piensa que se trata de una discriminación a la inversa. La posibilidad de adoptar medidas positivas en favor de grupos desfavorecidos queda aún más reforzada por las directrices de varios de los órganos de control encargados de interpretar los tratados de derechos humanos de la $\mathrm{ONU}$, los cuales han resaltado que estas medidas deben ser de carácter temporal y no prolongarse más allá de lo necesario para resolver la desigualdad en cuestión.

Los tribunales reconocen que se ha producido un trato diferenciado, pero puede estar justificado como acción positiva por el interés de corregir una desventaja previa, como la infrarrepresentación de determinados grupos en el lugar de trabajo. Ahora bien, los deportistas creyentes no constituyen un grupo desfavorecido o en desventaja por naturaleza, sino que han sido colocados en desventaja por las prohibiciones establecidas.

94 TEDH, Thlimmenos contra Grecia [GC] (núm. 34369/97), 6 de abril de 2000, párr. 44. Igualmente, TEDH Pretty contra el Reino Unido (núm. 2346/02), 29 de abril de 2002, párr. 88. 


\section{f) La acomodación razonable}

En los supuestos de ejercicio de la libertad religiosa en un ámbito laboral resulta esencial la acomodación salvo que se cause un duro gravamen al empleador. El concepto nació en los Estados Unidos de América y se ha extendido a la jurisprudencia laboral a nivel mundial.

Es conocido el caso del Tribunal Supremo de los Estados Unidos: Equal Employment Opportunity Commission v. Abercrombie \& Fitch Stores, Inc., núm. 14-86, de 1 de junio de 2015. Abercrombie no fue contratada por el hecho de llevar un velo. El empleador alegó que no tenía un conocimiento actual de las necesidades de la práctica de su religión por parte de quien optaba al puesto de trabajo ${ }^{95}$, pero el tribunal apreció discriminación.

The Equal Employment Opportunity Commission (EEOC) es una agencia gubernamental que debe imponer y vigilar el buen cumplimiento de las leyes antidiscriminatorias en el empleo. Una de estas leyes es la ley de derechos civiles de 1964, en cuyo título VII se prohíbe la discriminación sobre la base de la religión y se impele a los empleadores para acomoden la religión razonablemente, incluyendo «all aspects of religious observance and practice, as well as Belief» $[42 \text { U.S.C. } \$ 2000 \mathrm{e}(\mathrm{j})]^{96}$.

Siguiendo un estudio de Michael Sheehan ${ }^{97}$, no hay una jurisprudencia uniforme en los Estados Unidos de América ni en Europa, hay casos en los que prevalece el código sobre vestimenta de las empresas, en otros se respeta la indumentaria de los empleados.

En Daniels v. City of Arlington ${ }^{98}$, un policía pretendía llevar un pin con una cruz de oro, pero falló al reclamar que se acomodaran sus creencias y prácticas religiosas. El tribunal mantuvo que su petición de acomodación era irrazonable y suponía un duro gravamen para la ciudad, en cuanto constituía una cuestión de Derecho.

95 Vid. el comentario en Supreme Court of the United States: Equal Employment Opportunity Commission v Abercrombie E Fitch Stores, Inc., núm. 14-86, junio de 2015, en International Labor Rights Case Law, vol. 2 (2016), pp. 77-85.

96 Vid. el estudio sobre este tema de R. F. GREGORY, Encountering Religion in the Workplace. The Legal Rights and Responsibilities of Workers and Employers, Ithaca, Cornell University Press, 2011, pp. 1-274.

${ }_{97}$ M. SheEhan, «Managing Legal Conflicts When Business Dress Codes and Religious Dress Codes Clash», International Labor Rights Case Law, vol. 2 (2016), pp. 86-90.

98 Daniels v. City of Arlington, 246 F.3 ${ }^{\mathrm{d}} 500$ ( $5^{\text {th }}$ Cir. 2001). 
En Wilson v. US. West Communications ${ }^{99}$, el aspecto religioso del caso surgió del compromiso antiabortista de Wilson, por lo que llevaba fotos de un feto abortado en la solapa. Wilson no ofrecía alternativas como el uso de otro símbolo que expresara su compromiso, así que supuso un duro gravamen para el empleador.

EEOCv Kelly Services ${ }^{100}$. Kelly, una agencia de empleo, declinó contratar a una mujer que portaba un velo, puesto que se trataba de una empresa con una maquinaria de imprenta muy pesada y rotativa, motivo por el que no se permitía llevar ropa suelta ni nada que cubriese la cabeza. El tribunal sostuvo que la política del código de vestimenta se basaba en la seguridad y era neutral.

En otros supuestos, la vestimenta y, por tanto, las prácticas religiosas asociadas, prevalecen:

- United States v. New York City Transit Auth ${ }^{101}$. En este caso se derogó la prohibición de utilizar turbantes y khimars (túnicas negras) ${ }^{102}$, cuyo uso se basa en razones religiosas. La Autoridad de Tránsito prohibía todo aquello que cubriera la cabeza y no fuera oficial, como las gorras con logos. Rechazó una solicitud de que se permitiera a los empleados usar turbantes y khimars del mismo color que sus uniformes y pegar el logotipo en el bolsillo delantero o cuellos de las camisas de uniforme. El Tribunal falló contra la Autoridad de Tránsito.

- EEOC v. Reads, Inc. ${ }^{103}$. Un consejero de escuelas católicas, siguiendo la prohibición de contratar a personas que utilizasen atuendos religiosos, denegó una petición de trabajo a una musulmana, a pesar de que esta persona ofreció varias alternativas como una gorra de crochet o una bufanda atada. El tribunal consideró que no suponía un incumplimiento de contrato para el consejero el hecho de acomodarse a las prácticas religiosas de un empleado.

- En EEOC v. Red Robin Gourmet Burgers ${ }^{104}$, el empleado afectado era un camarero en el restaurante Red Robin que practicaba el

9958 F.3d 1337 (8 $8^{\text {th }}$ Cir. 1995). Vid. en https://caselaw.findlaw.com/us-8th-circuit/1054976.btml.

100598 F. $3^{\text {d }} 1022$ ( $8^{\text {th }}$ Cir. 2010).

10197 F.3 ${ }^{\mathrm{d}} 672$ ( $2^{\mathrm{d}}$ Cir. 1996).

102 Es una capa que cubre cabello, hombros y torso por encima de la cintura, pero deja al descubierto el rostro.

103759 F. Supp. 1150 (E.D. Pa. 1991).

1042005 WL 2090677 (WD. Wash. 2005). 
kemetecismo, una religión arraigada en el antiguo Egipto, y tenía dos tatuajes rodeando sus muñecas («Mi padre Ra es el Señor. Yo soy el hijo que existe de su Padre; Yo soy el Padre que existe de su hijo «). Red Robin le ordenó cubrir los tatuajes de acuerdo con la política de cuidado personal de la empresa, sin embargo, el camarero se negó alegando que era un pecado para él cubrir intencionalmente sus tatuajes, motivo por el que fue despedido. El Tribunal rechazó los alegatos de Red Robin, ya que no presentó evidencia de una queja del cliente o que los tatuajes visibles eran inherentemente inconsistentes con sus objetivos como restaurante familiar.

Canadá es otro país en el que la acomodación razonable ha originado un gran debate y una prolífica línea de investigación ${ }^{105}$. Cuando los miembros del gobierno del Partido Québécois propusieron su proyecto de una Carta de Valores de Quebec en 2013, crearon un nuevo frente en la controversia sobre acomodaciones religiosas que ha sido una parte importante y recurrente de los debates públicos de Quebec desde la decisión Multa$n i^{106}$ en 2006. La crisis llevó a la creación de la Comisión Bouchard-Taylor en 2007 ya citada en páginas precedentes, debido a escasos supuestos, pero impactantes, de acomodación religiosa irrazonable que involucraban un conflicto con otro derecho fundamental, como el derecho a la igualdad entre mujeres y hombres. Tras la emisión de ese borrador, el ámbito laboral se convirtió en el principal campo de batalla para un debate ideológico más amplio, como la cuestión de la legitimidad de imponer un límite estricto al derecho de los trabajadores del sector público de Quebec de portar símbolos religiosos en el lugar de trabajo, y hubo una lucha igualmente entre partidarios del multiculturalismo y el republicanismo que provocó una víctima colateral como era el modelo consensuado, diferenciado y pluralista de gestión de la diversidad religiosa y cultural en Quebec, la del interculturalismo.

El gobierno federal canadiense aprobó lo que equivale a la Constitución de 1982 importada de UK, compuesta por actas codificadas, tradicio-

${ }^{105}$ L. LAmmpron, «Competing visions of an inclusive society: The charter of Quebec values and the workplace», Canadian Labour and Employment Law Journal, vol. 20, núm. 2 (2017), pp. 339-354.

106 Multani v. Commission scolaire Marguerite-Bourgeoys, 2006 SCC 6, [2006] 1 SCR 256 [Multani].

En este caso, la Corte Suprema de Canadá permitió, bajo condiciones estrictas, que un niño usara un kirpan (un cuchillo de $20 \mathrm{~cm}$ con hoja de metal) en la escuela para cumplir con sus convicciones religiosas, vinculadas al Sijismo ortodoxo. 
nes y convenios, con la adquisición del espíritu propio de derechos y libertades de Canadá. Quebec se opuso a la Carta Canadiense de Derechos y Libertades, un capítulo de dicha Constitución.

Una de las principales incorporaciones legales del modelo canadiense de multiculturalismo se encuentra en la jurisprudencia sobre la interpretación de las disposiciones de la Carta Canadiense de Derechos y Libertades que protegen las creencias religiosas: 1) libertad de conciencia y religión y 2) el derecho a la igualdad, que prohíbe la discriminación religiosa. La Corte Suprema de Canadá se ha referido a menudo al art. 27 de la Carta en el proceso de interpretación de esas disposiciones. El art. 27 estipula que «esta Carta se interpretará de manera compatible con la preservación y mejora del patrimonio multicultural de los canadienses». Basándose en este principio, los tribunales canadienses han dado una interpretación extremadamente amplia y generosa de las creencias religiosas protegidas de los ciudadanos canadienses.

Los criterios jurisprudenciales basados en el caso Big M Drug Mart de $1985^{107}$ asientan ciertos principios:

- Que los poderes públicos deben mantener la posición de neutralidad religiosa cuando adopten o ejecuten sus decisiones. No obstante, pueden excepcionalmente expresar su afiliación religiosa, por ejemplo, mediante el uso de visibles símbolos religiosos ${ }^{108}$.

- Las convicciones espirituales exigen un comportamiento adecuado a las mismas en muchas ocasiones, pero no pueden ser impuestas a otros. Se toma una clara postura con respecto a la protección de las minorías frente a las religiones mayoritarias y su posible tiranía.

- La libertad de conciencia y religión protege a los creyentes, a los agnósticos y a los ateos.

- Se puede considerar que ha habido una restricción de las creencias religiosas, aunque la parte infractora no haya pretendido directamente causar una desventaja a un miembro de un grupo religioso.

Con estos principios, la sentencia Multani antes mencionada, y las recomendaciones del Informe de la Comisión Bouchard-Taylor, Quebec se desmarca y propone la Carta de Valores de Quebec en 2013 que, como advertimos anteriormente, provoca una disputa entre los seguidores del modelo

${ }_{107}$ Rv Big M Drug Mart Ltd, [1985] 1 SCR 295, 60 AR 161 [Big M Drug Mart].

${ }^{108}$ L. BARNETT, «Signes religieux dans la sphère publique et liberté de religion», Ottawa, Bibliothèque du Parlement, 2008, disponible en bttp://publications.gc.ca/collections/ Collection-R/LoPBdP/PRB-f/PRBO441-f.pdf. 
del multiculturalismo y del republicanismo. El republicanismo importado de Francia ignora las diferencias individuales, excepto la discapacidad, para asegurar la igualdad de los ciudadanos y, por tanto, se prohíbe el uso de símbolos religiosos en el lugar de trabajo. Esta estricta prohibición va en contra de una posición pluralista, del respeto a la neutralidad en materia religiosa, y no tiene una base sólida en el respeto a la libertad religiosa o en la protección de la seguridad pública, puesto que no se ha demostrado que la indumentaria o los símbolos religiosos dinámicos sean un motor de transmisión de creencias considerado como un comportamiento o actitud proselitista. Sin embargo, esta es la imposición quebequense y se basa en la decisión del Consejo de Estado francés, de $2000^{109}$, en la que se establece que los funcionarios públicos no tienen el derecho de expresar sus convicciones religiosas en el lugar de trabajo ni usar símbolos religiosos. Se puede decir que a pequeña escala es un holocausto para los creyentes en el espacio laboral ${ }^{110}$ que se ven afectados por la relación entre el Estado y la Religión, asfixiando el efecto horizontal.

Estados Unidos de América y Canadá han protagonizado los debates más interesantes en materia de acomodación razonable, aunque luego se haya trasladado a Europa donde tenemos una buena cantera de jurisprudencia en la que la acomodación no tiene cabida, limitándose el derecho de libertad religiosa si se demuestra que concurre un fin legítimo, proporcionado y necesario en una sociedad democrática. Esta justificación de los recortes en materia de derechos humanos y de igualdad, va asociada a muchos supuestos tipificados en el ámbito penal y que han ido transformándose como la blasfemia, ofensa a los sentimientos religiosos, difamación y, actualmente, la incitación al odio y a la violencia, el delito de odio.

En el espacio europeo, el Tribunal Europeo de Derechos Humanos tampoco es uniforme, intenta conciliar posiciones, pero admite por ejemplo, la prohibición del burka por Francia, así como de toda indumentaria religiosa en lugares públicos ${ }^{111}$.

En el asunto S.A.S. c. Francia, la demandante acude ante el TEDH alegando una violación de los arts. 8 (respeto de la vida privada y familiar), 9

109 Avis Dlle Marteaux, RFD adm 2001.

110 Hasta las guerras napoleónicas, los judíos han sido el blanco de la discriminación. No podían residir en determinadas ciudades, estaban excluidos de algunas actividades profesiones, y no podían practicar sus creencias religiosas en la esfera pública. comenzaron a tener el estatus de ciudadanos y a ejercer su libertad religiosa sin restricciones en el siglo XIX, pero luego vivieron el holocausto con el régimen nazi del siglo xx.

${ }^{111}$ La sentencia del TEDH en el asunto S.A.S. c. Francia [GC], núm. 43835/2011, ECHR 2014, sobre la prohibición del velo integral en lugares públicos. 
(libertad religiosa) y 10 (de expresión), ya que no podía llevar el velo integral en público. Finalmente, basándose en el art. 14 CEDH (prohibición de discriminación), considera que la prohibición de llevar el burka y el nicab discriminaba a las mujeres como ella, por motivos de sexo, religión y origen étnico. Este caso tiene la particularidad de que en el procedimiento escrito, con base en el art. 36.2 del Convenio, intervinieron los Gobiernos belga y holandés, el Centro de Derechos Humanos de la Universidad de Gante y organizaciones no gubernamentales como Amnistía Internacional, lo cual muestra la relevancia de la decisión que ha tomado el TEDH en este caso.

Lejos de la acomodación, los jueces han estimado que la prohibición decretada por las autoridades puede ser proporcional y necesaria en el marco de una sociedad democrática. Los jueces de Estrasburgo responden así en nombre de la fraternidad y el principio «living together» ${ }^{112}$. Sin embargo, en su fundamentación previa reconoce que ha habido una interferencia continuada en el ejercicio de los derechos de la demandante con base en los arts. 8 y 9, ya que la Ley le planteaba un dilema: o respetar la prohibición, y por consiguiente renunciar a vestirse de acuerdo con su visión de la religión; o incumplir la Ley y afrontar sanciones penales. El Tribunal subraya que la interferencia persigue dos de las finalidades legítimas contempladas en los arts. 8 y 9 , la seguridad pública y la protección de los derechos y libertades de los demás. No considera que la prohibición general del uso del velo integral garantice la seguridad pública. Con respecto a la protección de los derechos y libertades de los demás, admite únicamente que afecta a unos mínimos requerimientos de interacción en la vida social, pero tampoco constituye un serio obstáculo. Llega incluso a expresar que esta prohibición crea estereotipos que pueden promover la

112 "The applicant is a French national who was born in 1990 and lives in France. In the applicant's submission, she is a devout Muslim and she wears the burqa and niqab in accordance with her religious faith, culture and personal convictions. According to ber explanation, the burqa is a full-body covering including a mesh over the face, and the niqab is a full-face veil leaving an opening only for the eyes. The applicant emphasized that neither her busband nor any other member of her family put pressure on her to dress in this manner. The applicant did not claim that she should be able to keep the niqab on when undergoing a security check, at the bank or in airports, and she agreed to show her face when requested to do so for necessary identity checks. Since 11 April 2011, the date of entry into force of Law num. 2010-1192 of 11 October 2010 throughout France, it has been probibited for anyone to conceal their face in public places. The report further found that the full-face veil represented a denial of fraternity, constituting the negation of contact with others and a flagrant infringement of the French principle of living together (le «vivre ensemble»)», disponible en http://hudoc.echr.coe.int/eng?i=001145466 (consultado el 1 de enero de 2018). 
intolerancia religiosa. No obstante, cede ante la prohibición porque Francia tiene un amplio margen de apreciación, como todos los Estados que han ratificado la Convención, además, la elección de si se permite o no el velo, depende de cada sociedad, así que en este caso y aunque no haya un consenso europeo en la materia, resulta proporcionada la finalidad de proteger las condiciones de «vida en comunidad». Como advierte Martínez Torrón ${ }^{113}$, no corresponde a los tribunales decidir sobre las políticas públicas relativas a símbolos religiosos, y menos aún al Tribunal Europeo de Derechos Humanos. Los tribunales no son legisladores, ni tampoco policy makers. Su función consiste en aplicar el derecho vigente, en decidir quién posee el derecho prevalente en caso de conflicto.

La historia social y política de cada país condiciona su actitud ante la libertad religiosa y sus manifestaciones, también su sociedad en clave de religión influye en los datos de ocupación laboral, y el derecho tiene que corregir las desigualdades. Mientras Francia se preocupa por expulsar a Dios de los lugares públicos, en otras zonas como el norte de Irlanda, las cifras del censo de desempleo de católicos reflejaban que era mucho más alto que el de los protestantes porque la religión es un factor clave ${ }^{114}$. Incluso en la construcción donde los católicos son líderes, las estimaciones de desempleo seguían siendo altas, aunque también influye que los católicos formaban familias numerosas, difíciles de sostener, por lo que los índices de pobreza eran altos, habitaban en suburbios. Las primeras leyes antidiscriminación no podían remediar centurias de prejuicios y discriminación pero sí constituyeron un escalón revolucionario que situó en mejor posición a los católicos. Y es que no se trata de cambiar ni de expulsar el factor religioso de la sociedad, sino de limitar el ejercicio indebido de la libertad religiosa y las actitudes sociales que violan el ejercicio de otros derechos de los demás ${ }^{115}$.

113 J. MartíneZ TorRón, «Símbolos religiosos institucionales, neutralidad del Estado y protección de las minorías en Europa», Ius Canonicum, vol. 54 (2014), pp. 107-144.

${ }^{114}$ L. M. CURRIERT, «Religion and employmet in Nothern Ireland: U.S. Influence on antidiscrimination legislation», Comparative Labor Law Journal, vol. 12, núm. 1 (1990), pp. $73-105$.

115 «En el número anterior de esta REVISTA (núm. 194, pp. 261-264) me refería, por ejemplo, a la protección de la salud pública como bien que deberá prevalecer sobre la libertad religiosa, en el primer caso que llega a Estrasburgo planteado por una representante de la Comunidad Daimista, en la que sus ritos no tienen sentido sin el consumo de ayahuasca (Decisión de Inadmisión Alida Maria Fränklin-Beentjes y Ceflu-Luz da Floresta c. Holanda, de 6 de mayo de 2014). También deberá ceder el ejercicio individual de la libertad religiosa cuando ocasione problemas de orden público. Así, en la Decisión de Inadmisibilidad Rosemary Fairfield y otros c. el Reino Unido, de 8 de marzo de 2005, se conde- 
En Alemania, se prevén sanciones por discriminación en razón de creencia religiosa. La víctima puede reclamar el daño material y el inmaterial $^{116}$. Distinto es el caso de empresas consideradas sociedades religiosas en las que los empleados tienen un deber de lealtad asociado al dogma religioso de la empresa que puede afectar incluso a su vida privada. Se exige más a las sociedades seculares que a las religiosas, aunque estas también estén siendo objeto de conflicto judicial.

En el Reino Unido ${ }^{117}$, no hay una separación entre lo público y lo privado en el empleo. Hay abstencionismo en lo que a la religión se refiere, y si se trata de organizaciones religiosas, se considera algo espiritual, existe algo de resistencia a considerar que hay relaciones contractuales. La ley de igualdad en el empleo de 2003 protege contra la discriminación en razón de religión, el prejuicio o el rechazo no razonable para adaptar prácticas relativas a la indumentaria o al tiempo de trabajo, lo mismo si ya está empleado.

Bajo la ley de igualdad de 2006, también se califica como discriminación que no se contrate a una persona por la falta de compromiso con la religión. Ahora bien, el art. 7 (2) establece que la obligación de no discriminación no se aplica cuando se tiene en cuenta la naturaleza del empleo o el contexto en que se lleva a cabo:

a) ser de una religión particular es un hecho genuino y un determinante requisito ocupacional.

b) es proporcionado aplicar ese requisito en el caso.

La no discriminación está en relación con la libertad religiosa garantizada en la ley de derechos humanos de 1998, prácticamente una repetición del Convenio de derechos humanos de 1950.

Una vez que el empleado ha demostrado que una práctica le pone en desventaja, entonces le corresponde al empleador demostrar que el requi-

nó a un pastor evangélico que iba de ciudad en ciudad exhortando proclamas en contra de la homosexualidad, lo que solía molestar y ofender, ocasionando desórdenes públicos. Por ello, el TEDH entendería que la respuesta policial y judicial ante el desorden provocado por el religioso, tratando de fomentar el rechazo hacia las minorías sexuales, constituye una necesidad legítima en una sociedad democrática que justifica una limitación de la libertad de expresión de la religión» [O. BOUAZZA ARIÑo, «Notas de Jurisprudencia del Tribunal Europeo de Derechos Humanos», Revista de Administración Pública, núm. 206 (2018), p. 234].

116 A. SEIFERT, «Religious expression in the workplace: The case of the federal republic of Germany», Comparative Labor Law E Policy Journal, vol. 30, núm. 3 (2009), pp. 529-568.

117 M. FREEDLAND y L. VICKERS, «Religious Expression in the Workplace in the United Kingdom», Comparative Labor Law E Policy Journal, vol. 30, núm. 3 (2009), pp. 597-626. 
sito está justificado como un medio proporcionado para lograr un objetivo legítimo. Ejemplos de discriminación indirecta justificada ${ }^{118}$ en la jurisprudencia temprana incluyen a James $v$. MSC Cruises ${ }^{119}$ donde se dictaminó que exigir trabajar a un adventista del séptimo día los sábados era justificable por motivos comerciales, y Azmi v. Consejo Metropolitano de Kirklees ${ }^{120}$ donde la negativa a permitir a una enseñante el uso de un velo que cubriera su rostro se admitió como justificado y necesario, ya que se defendía los intereses de los niños en recibir la mejor instrucción posible.

La mayoría de los casos en el Reino Unido hacen referencia al uso del velo y, en este caso, se debe tener en cuenta un factor como es la interacción entre la libertad religiosa y libertad de expresión. El uso de velo es un acto expresivo, y puede tener varios significados, de modo que al intentar encontrar una justificación o proporcionalidad en las restricciones del empleador, los tribunales deben ser cautelosos de interpretar en nombre de las mujeres el significado de sus acciones.

El Reino Unido también se ha visto en la encrucijada ante el Tribunal Europeo de Derechos Humanos. En Eweida and Others v. United Kingdom, la Corte se enfrentó a cuatro solicitantes cristianos que argumentaron que las políticas laborales en relación con la vestimenta o la no discriminación por motivos de orientación sexual, violaban sus derechos a la libertad de religión (art. 9) o a la no discriminación (art. 14) en relación con el disfrute de los derechos protegidos por la Convención Europea de Derechos Humanos (CEDH) ${ }^{121}$. A la primera demandante, Nadia Eweida, le fue denegado el permiso de British Airways para llevar una cruz sobre su uniforme. A la segunda, Shirley Chaplin se le impidió por sus empleadores llevar una cruz en una cadena alrededor de su cuello en su trabajo como enfermera basándose en que representaba un riesgo de lesiones si se rasgaba, ya que trabajaba con pacientes que padecían un riesgo de infección. Tanto el tercero como el cuarto demandante impugnaron el requerimiento por parte de los empleadores de políticas contra la discriminación, exigiéndoles la atención a los clientes sin discriminar por motivos de orientación sexual, lo que supuso un cauce amplio para los empleadores que les faculta para ir en contra de la libertad de

${ }_{118}$ L. VICKERS, Religious Freedom, Religious Discrimination and the Workplace, London, Hart Publishing, 2008.

119 James v. MSC Cruises Case 2203173/05 (2007) 157.

${ }_{120}$ Azmi v. Kirklees Metropolitan Council [2007] ICR 1154.

${ }^{121}$ Vid. un comentario por Sir T. ETHERTON, «Religion, Rule of Law and Discrimination», Ecclesiastical Law Journal, vol. 16 (2014), pp. 265-282. 
conciencia ${ }^{122}$. Lillian Ladele era registradora civil del distrito de Islington, fue sancionada por violar la política de 'Dignidad para todos' de su empleador al negarse a registrar asociaciones sobre la base de su creencia de que la homosexualidad es un pecado. Gary McFarlane, un terapeuta sexual, fue despedida por una organización benéfica de asesoramiento al negarse a proporcionar terapia sexual a parejas del mismo sexo de conformidad con sus creencias.

De los cuatro, solo la Sra. Eweida tuvo éxito. La Corte decidió por cinco votos a favor que la negativa de British Airways a permitirle llevar su cruz fue desproporcionada y que al transigir con esta interferencia desproporcionada a la libertad religiosa que está protegida por el art. 9, los tribunales británicos habían violado la Convención ${ }^{123}$.

En Eweida no había riesgo de adoctrinamiento con menores, ni peligro para la integridad física, ni sus actos acordes con sus creencias suponían una discriminación hacia otros, así que se esperaba de British Airways una acomodación al uso de un símbolo religioso como manifestación de sus creencias religiosas. David Cameron, entonces primer Ministro, declaró que reformaría la ley para permitir los símbolos religiosos en el lugar de trabajo, sin embargo, los expertos en Derecho laboral reprobaron estas declaraciones ${ }^{124}$ y parte de la opinión pública se opone al uso de símbolos de este tipo ${ }^{125}$.

En España, la acomodación o el ajuste razonable en el trabajo se puede encontrar en el mismo Estatuto de trabajadores, por ejemplo, la reducción de jornada por cuidar a un familiar enfermo, una especie de derecho a alterar las condiciones pactadas en el contrato de trabajo.

Sin embargo, no es lo mismo ejercer un derecho previsto en la ley que no altera la buena fe contractual, que el uso de símbolos religiosos o el ejercicio de la libertad religiosa con otro tipo de manifestaciones de la misma, o el uso de la libertad de expresión, existiendo otros intereses jurídicos en la relación contractual. Se deben ponderar los derechos en juego, e incluso tener en cuenta la prevención de riesgos laborales, y aun así, partiendo de la dignidad de la persona como fundamento del ordenamiento

${ }_{122}$ R. MCCREA, «Religion in the Workplace: Eweida and Others $v$ United Kingdom», Modern Law Review, vol. 77, núm. 2 (2014), p. 288.

${ }^{123}$ Chicago $7^{\text {th }}$ ed., European Employment Law Cases 2010, núm. 2 (2010), pp. 17-18.

124 «Cameron vows to "change the law" to allow religious symbols at work Anonymous Employers' Law», ProQuest Central, septiembre de 2012, p. 5.

125 «Neil Addison Banning religious symbols should not be discriminatory», The Daily Telegraph, 16 de octubre de 2006. Documentos de Proquest: http://0-search.proquest.com. cisne.sim.ucm.es/docview/321385967? accountid $=14514$. 
jurídico, el trabajo debe adaptarse a la persona. Para prevenir riesgos laborales se exige la adaptación del ambiente físico, social y actitudinal de las necesidades específicas del trabajador siempre que no suponga una carga desproporcionada indebida, aunque a veces resulte imposible o deficiente, pero se deben poner los medios. Todo esto parece muy loable en el sector del empleo si hablamos de personas con discapacidad, o cuestiones de género, sin embargo, pisando el terreno de la libertad religiosa cambia la disposición hacia dicho ajuste o adaptación a la persona. Sería más asequible si únicamente se aplicara el principio de no injerencia, pero el derecho de libertad religiosa también tiene una vertiente positiva que es donde entra la posible acomodación.

Por la fuerza expansiva del derecho de libertad religiosa, y las partes implicadas en la prestación por cuenta ajena, empresario, empleado, terceros o incluso la propia administración, no existe un fórmula magistral para dar respuesta a estas demandas en el ámbito laboral, de ahí que la acomodación a modo de conciliación, o la alternativa judicial como es el arbitraje laboral y/o deportivo, sería la mejor vía para ser equitativos. La libertad religiosa colisiona a veces con la libertad de empresa, pero como dicen Rodríguez Piñero y Bravo Ferrer, la racionalidad económica no puede ser el único factor de legitimación de las decisiones empresariales cuando estas afectan a los derechos fundamentales del trabajador como productor y como persona ${ }^{126}$.

Si no hay ajuste y el caso se judicializa, será el juez el garante de la libertad religiosa y del pluralismo religioso existente en la sociedad, a falta de desarrollos legales en esta cuestión, siempre enmarcándose en el caso concreto, y en el derecho constitucional a la libertad de empresa como contrapeso en la ponderación.

\section{CONCLUSIONES}

\section{La neutralidad del deporte y la identidad del deportista}

El ánimo de crear una identidad cultural común a través del deporte, no es exigencia de encefalograma plano o muerte cerebral para los deportistas en lo que a cultura propia e identidad se refiere. Obligar a un depor-

126 M. Rodríguez Piñero y Bravo Ferrer, «Derechos fundamentales del trabajador, poderes empresariales y contrato de trabajo», en AA.VV., El trabajo y la Constitución. Estudios en homenaje a Alonso Olea, Madrid, Ministerio de Trabajo y Asuntos Sociales, 2003, p. 542.

Foro, Nueva época, vol. 23, núm. 1 (2020): 155-220 
tista a no hacer la señal de la cruz antes de un partido, o manifestaciones similares, resulta hipócrita, puesto que se ha demostrado que el deporte tiene y es ideología cuando se utiliza como arma propagandística. Que tenga universalmente un contrapeso ético, no significa que sea ni haya sido siempre completamente neutral, de ahí que se deba otorgar la oportunidad de ser líderes a los deportistas, con el empoderamiento no solo por razón de sexo o género, sino para hacer efectivos los objetivos del año internacional del deporte, que a través del acceso y participación en el deporte se proporcione una oportunidad para 'aprender a vivir en paz y preservar a la vez las identidades culturales de todas las partes' ${ }^{127}$.

El respeto a la interculturalidad, a las identidades diferentes, requiere la neutralidad del Estado que se vierte sobre el Consejo del Deporte y todos los entes en la organización del deporte, pero no la del deportista ni la de los aficionados al deporte, de modo que cualquier recorte en libertades debe estar justificado, prescrito por ley, y admitir excepciones por exención en casos específicos o por acomodación razonable, aunque en el deporte ya sabemos que el arbitraje es una alternativa prioritaria. Los árbitros son especialistas en derecho del deporte ${ }^{128}$, habría que cuestionarse si también en derechos fundamentales, ya que debería dilucidarse ante el Tribunal Constitucional, mientras las Cortes de Arbitraje no tengan este tipo de jurisdicción, en el caso de que los clubes u otros organismos deportivos lesionen los derechos fundamentales del deportista.

\section{La libertad de conciencia religiosa en el uso de símbolos y la expresión de las convicciones religiosas}

La justicia europea irrumpe en el debate sobre el uso visible de cualquier signo político o religioso en el ámbito de las relaciones laborales abordando el debate sobre la prohibición del velo islámico en el marco laboral. Siguiendo la Directiva 2000/78 relativa al establecimiento de un marco general para la igualdad de trato en el empleo y la ocupación, se da autonomía y libertad al empresario para implantar un régimen de neutralidad política, filosófica y religiosa en las relaciones con sus clientes, siem-

127 Declaración del Año internacional del Deporte, disponible en https://www.un.org/ es/events/pastevents/sport2005/ (consultado el 23 de noviembre de 2019).

${ }^{128}$ L. M. CAzOrLa PrIETO, «El arbitraje deportivo», Revista jurídica de Castilla y León, núm. 29 (2013). 
pre que los medios para la consecución de una finalidad legítima sean adecuados y necesarios.

En cuanto a la libertad de expresión, se ha pasado de una protección legal especial contra el discurso antirreligioso hacia grupos religiosos o hacia sus adeptos, a un trato de favor hacia la libertad de expresión, salvo que se incite a la violencia y a la discriminación, perturbando la paz, así se aprecia en las Resoluciones y Recomendaciones del Consejo de Europa. La Asamblea Parlamentaria del Consejo de Europa aprobó la Resolución 1510 (2006), sobre libertad de expresión y respeto a las creencias religiosas ${ }^{129}$, en la que se recuerda la doctrina del Tribunal Europeo de Derechos Humanos, según la cual las expresiones que pueden ofender las convicciones personales, morales o religiosas, pueden ser objeto de mayores restricciones que las que tienen por objeto asuntos políticos o de interés público, con todo no se pueden establecer restricciones adicionales a la libertad de expresión para acomodarse a las sensibilidades de distintos grupos religiosos. Esta Resolución, al igual que la Recomendación 1805 (2007), de 29 de junio, sobre blasfemia, insultos religiosos y hate speech contra personas por razón de su religión ${ }^{130}$, consideran que solo una incitación para perturbar la paz o hacia el empleo de la violencia y la discriminación contra las personas o grupos de personas pueden restringir la libertad de expresión, porque lo demás entra en el ámbito del debate público propio de una sociedad democrática, además se protege a las personas, no a la religión en sí misma.

Si en octubre de 2019 apareció la noticia en los medios de comunicación sobre dos jugadores de fútbol italianos que habían sido sancionados por blasfemar en mitad de un partido, siendo suspendidos con un partido por «tomar el nombre de Dios en vano», no extraña que ante las críticas por estas medidas, se hayan planteado prohibir tanto el discurso antirreligioso como el religioso, ahora bien, la libertad de expresión también es una derivación del fuero interno relacionado con la libertad de pensamiento y de conciencia ${ }^{131}$, de ahí que deba determinarse caso por caso

129 Disponible en https://www.europarl.europa.eu/sides/getDoc.do?pubRef=-//EP// TEXT+TA+P6-TA-2006-0064+0+DOC+XML+V0//ES (consultado el 12 de diciembre de 2019).

${ }^{130}$ En Revista General de Derecho Canónico y Derecho Eclesiástico del Estado (2007), Documentación. También en http://www assembly.coe.int/nw/xml/XRef/Xref-DocDetailsEN.asp?FileID=17569 (consultado el 12 de diciembre de 2019).

${ }^{131}$ La libertad de expresión también es una derivación del fuero interno relacionado con la libertad de pensamiento y de conciencia: «Article 9 also protects acts intimately linked to the forum internum of personal belief. The specific textual reference to the "freedom, either alone or in community with others and in public or private, to manifest [one's] religion or 
poniendo el termómetro del hate speech. Aunque suponga una cierta intrusión en el fuero interno, es una medida más sensata que la prohibición generalizada.

\section{La prescripción por ley de la limitación a los derechos humanos}

El desarrollo de los estándares de derechos humanos dentro del marco de la Convención Europea ha priorizado siempre la promoción de la dignidad. Con todo, debido al incremento del pluralismo religioso en el siglo XXI, las leyes más que dirigirse al reconocimiento y garantía de la libertad religiosa, proliferan en orden a establecer medidas de integración y de políticas en materia de seguridad ${ }^{132}$. Haciendo frente a la natural secularización de la sociedad, resulta difícil un modelo jurídico respetuoso de las creencias religiosas e ideológicas de la población ${ }^{133}$.

Cómo encontrar un punto de inflexión, un acomodo razonable entre lo hiriente y el ejercicio legítimo de un derecho, nos podría llevar a casos como las caricaturas o el supuesto de Charlie Hebdo, que abocaron en el terrorismo yihadista, y dieron lugar a muchas manifestaciones anti-islámicas de carácter civil y político. Manifestarse ideológica o religiosamente no debe estar sujeto a prohibiciones salvo que se incite al odio y a la violencia en contra de personas o grupos de personas, algo diferente al desahogo de un futbolista italiano que al fallar un gol, blasfemó contra Dios y la Virgen, hecho por el que fue sancionado.

En el ámbito laboral hay un supuesto de restricción justificada. Los derechos humanos están comprometidos cuando la organización empre-

belief, in worship, teaching, practice and observance" underlines that manifestation of belief is an integral part of the protection accorded by the guarantee. For example, "bearing witness in words and deeds is bound up with the existence of religious convictions". However, since such "manifestations" of thought, conscience or religious belief at times may appear indistinguishable from the expression of thought or conscience falling within the scope of Article10's guarantee of freedom of speech, care must be taken in determining which guarantee ought to apply» (en Protecting the right to freedom of thought, conscience and religion under the European Convention on Human Rights, Strasbourg, Council of Europe human rights handbooks, 2012, p. 21).

132 Vid. sobre el tema en Austria. R. Pотz, «The Pluri-Religious Challenge of a Secular State», en Religion and Secularism in the European Union. State of Affairs and Current Debates, Brussels, Peter Lang, 2017, p. 19.

133 Vid. R. Valencia Candalija, «¿Está la religión en fuera de juego?: reflexiones relativas a la presencia de símbolos religiosos en el fútbol», Anuario de Derecho Eclesiástico del Estado, núm. 34 (2018), pp. 25-261. 
sarial tiene un determinado ideario. Así, por ejemplo, si se expresan ideas contrarias a las que identifican a un centro escolar privado y religioso, o se usa una indumentaria prohibida por motivos religiosos o por compromiso con la neutralidad, basándose en el ethos de la empresa.

En el mundo del deporte no hay estrictamente un ideario o ethos propios aunque sean palabras que se incluyan en el lenguaje de los directivos, así la percepción de un atentado a la disciplina y al decoro deportivo por ciertas manifestaciones religiosas (símbolos o discurso) no implica necesariamente una contradicción con un ideario, ni que se genere violencia, atentando contra los derechos de los demás, la salud o la seguridad públi$\mathrm{ca}$, porque entonces también deberíamos prohibir lo que más violencia y odio genera, las camisetas, bufandas y otros artículos de los deportistas e hinchas del equipo contrario. Ahora bien, aunque todos los supuestos exigen la equidad, la justicia del caso concreto, mucho más si se trata de los días de descanso coincidente con competiciones o entrenamiento, o del ayuno, por ejemplo.

En todo caso, cualquier limitación de la libertad religiosa debería estar «prescrita por ley» ${ }^{134}$. Siguiendo el lema francés «Le vivre ensemble», conocido más como «living together», la justificación para que el derecho de manifestación de la propia religión o creencia, cualificado como derecho, pueda ser limitado si está prescrito por ley, es que se esté persiguiendo un propósito legítimo, necesario en una sociedad democrática y, por tanto, proporcionado ${ }^{135}$.

\section{La discriminación directa e indirecta en el ámbito laboral y su estudio en el espacio deportivo}

En la normativa española encontramos leyes que definen los contornos de ambos tipos de discriminación, directa e indirecta. En algunas leyes españolas, a pesar de mencionarse a la religión y a las convicciones como factores para la discriminación, esta viene principalmente regulada de la mano de la igualdad por razón de sexo, género y discapacidad en el ámbito

134 Vid. el artículo de J. M. GonZÁLEZ del VALLE, «Restricciones a la libertad religiosa», Sociedad, Derecho y Factor Religioso. Estudios en honor del Profesor Isidoro Martín Sánchez, Granada, Comares, 2017, pp. 283-304.

135 Vid. sobre este tema I. M. BRIONES MARTínez, El Delito de odio por razón de religión y de creencias. La educación en la religión contra el terrorismo de la palabra y de la violencia, Cizur Menor, Aranzadi, 2018, p. 36. 
del empleo. Quizá por este motivo debemos atender a la normativa internacional y más concretamente la europea que ofrece una perspectiva un poco más amplia dentro del ámbito laboral.

Podemos describir de modo más detallado la discriminación siguiendo el Manual de Legislación Europea contra la Discriminación, y comprobamos que la religión y las convicciones están entre los motivos protegidos contra la discriminación. Hay al menos cuatro formas en que un reclamo de acomodación de las creencias religiosas que podrían presentarse bajo el CEDH, las dos primeras involucran libertad y los dos últimas implican igualdad. Las normativas de la UE y el CEDH están actualmente estrechamente vinculadas.

No se requiere ser reiterativo en definiciones, así que partiendo de lo que significa la discriminación directa e indirecta en el ámbito laboral, la mayoría de los supuestos en el deporte constituyen una discriminación indirecta, ya sea por protección del orden público que afecta a la libertad de expresión o al uso de símbolos — nos podemos encontrar también con casos de discriminación directa-; por la defensa de la integridad física del deportista, por el uso de determinados símbolos que la ponen en peligro, o por la práctica de imperativos religiosos como puede ser el ayuno que afecte a su salud y no solo a su rendimiento; o en virtud del interés empresarial — organizaciones deportivas de distinto nivel— como la fijación de fechas inamovibles locales, nacionales e internacionales para los eventos deportivos que altera los días de descanso o el tiempo de oración de algunos deportistas que profesan una religión que les impele a ello.

Siguiendo la idea de Mantecón Sánchez, las leyes aparentemente neutrales que imponen modelos de conducta, se resuelven en medidas que atentan directamente contra las convicciones de un importante sector de la ciudadanía ${ }^{136}$, y si no se quiere invocar el principio de libertad religiosa al menos debería actuarse en razón de un principio de equidad ${ }^{137}$.

Quizá con este objetivo se promocionan las medidas especiales. Para corregir y evitar este tipo de situaciones, los gobiernos, los empleadores y los prestadores de servicios deben asegurarse de adoptar medidas para ajustar sus disposiciones y prácticas con el fin de tener en cuenta estas diferencias; es decir, deben hacer algo para adaptar sus políticas y medidas vigentes. En el ámbito de la ONU, se denominan medidas especiales,

136 J. MANTECón SÁnCheZ, «España: Estado en una sociedad secularizada», Sociedad, Derecho y Factor Religioso. Estudios en honor del Profesor Isidoro Martín Sánchez, Granada, Comares, 2017, p. 344.

${ }^{137}$ Ibid., p. 347. 
mientras que en el derecho de la UE se habla de medidas específicas o de acción positiva. Con estas medidas, los gobiernos pueden asegurar la igualdad sustantiva, a cuya promoción se obliga a los poderes públicos en nuestro art. 9.2 de la Constitución española.

\section{La acomodación razonable de la libertad de conciencia religiosa}

El concepto nació en los Estados Unidos de América y se ha extendido a la jurisprudencia laboral a nivel mundial.

Ya que la legislación debe inspirarse siempre en un propósito secular, los clubes como parte empresarial deben buscar la acomodación razonable a las prácticas religiosas ${ }^{138}$, salvo que supongan un duro gravamen ${ }^{139}$, más que la limitación o restricción, y recalcando que no cualquier acomodación puede considerarse legítima jurídicamente, sino que será importante que tal acomodación o modulación de la relación laboral sea razonable y suficiente ${ }^{140}$.

No hay una jurisprudencia uniforme en los Estados Unidos de América ni en Europa, hay casos en los que prevalece el código sobre vestimenta de las empresas, en otros se respeta la indumentaria de los empleados. Canadá es otro país en el que la acomodación razonable ha originado un gran debate y una prolífica línea de investigación, y ante las dificultades para acomodarse a ciertas prácticas religiosas, se tiende más a la conciliación y el arbitraje.

En efecto, la acomodación razonable de los derechos fundamentales podría contar con un aliado, el arbitraje. Conocedores de que está en boga el arbitraje deportivo, la mediación y la conciliación, quizá se debería recurrir a los mismos medios alternativos para el caso de manifestaciones teísticas o no en el ámbito del deporte, de cara a evitar una situación quimérica, como intento de razonable acomodación extra-judicial ${ }^{141}$, un remedio para encontrar soluciones a disputas entre las partes contendientes, evitando la

\footnotetext{
138 Vid. sobre la acomodación razonable I. M. BRIOnEs Martínez, El Factor Religioso y las Autonomías, Granada, Comares, 2011.

139 B. J. Redman, «Sabbatarian Accomodation in the Supreme Court», Journal of Church E State, vol. 3, núm. 3 (1991), pp. 495-524.

140 R. K. Aparicio Aldana, «La libertad religiosa y de conciencia en las relaciones de trabajo. Un intento de armonización desde el Derecho español y lo resuelto por el Tribunal Europeo de Derechos Humanos», Revista Latinoamericana de Derecho y Religión, vol. 2, núm. 1 (2016), p. 5.

${ }^{141}$ Vid. un interesante estudio en el ámbito norteamericano sobre la acomodación razo-
} 
demora judicial y los costes de la misma, tanto monetarios como morales, así se hará realidad la contribución del deporte como socio para el logro del desarrollo humano y la paz duradera, realzando puntos en común, y superando las brechas culturales y étnicas.

Si no hay ajuste y el caso se judicializa, será el juez el garante de la libertad religiosa y del pluralismo religioso existente en la sociedad, a falta de desarrollos legales en esta cuestión, siempre enmarcándose en el caso concreto, y en el derecho constitucional a la libertad de empresa como contrapeso en la ponderación.

\section{El deporte como hacedor de la paz}

Se utiliza el deporte para conseguir la paz frente a la intolerancia religiosa y cultural, así se declaraba en el año internacional del deporte: «El deporte, como lenguaje universal, puede ser un poderoso vehículo para fomentar la paz, la tolerancia y la comprensión. Mediante su poder para unir a los pueblos a través de las fronteras, las culturas y las religiones, puede fomentar la tolerancia y la reconciliación. El deporte, por ejemplo, ha ayudado a reiniciar diálogos cuando otros canales han fracasado: Norcorea y Corea del Sur juntaron sus atletas en un solo equipo para los juegos Olímpicos de Sydney 2000; el tenis de mesa abrió el camino para la reanudación de las relaciones diplomáticas entre China y Estados Unidos en 1971, y en la actualidad, niños israelitas y palestinos se reúnen regularmente para jugar fútbol o básquetbol» ${ }^{142}$.

No obstante, utilizar la universalidad del deporte para unir, no significa acallar la libertad de expresión, verbal y simbólica, de los deportistas como manifestación de su libertad de creencias, a veces incluso como imperativos de conciencia. No convirtamos las manifestaciones religiosas en el deporte en un punto caliente más que desencadene en guerras culturales $^{143}$, sino en un peacemarker mundial ${ }^{144}$.

nable en el atletismo. S. C. IDLEMAN, «Religious Freedom and the interscholastic athlete», en Marquette Sports Law Review, vol. 12 (2001), pp. 295-345.

142 https://www.un.org/es/events/pastevents/sport2005/ (consultado el 15 de diciembre de 2019).

143 R. Chapman, Culture Wars: An Encyclopedia of Issues, Viewpoints, and Voices, 2 vols., Armonk, New York, M. E. Sharpe, 2009. ProQuest Ebook Central, https://ebookcentral.proquest.com/lib/universidadcomplutense-ebooks/detail.action?docID $=501518$ (consultado el 3 de enero de 2020).

${ }^{144}$ Religion and Peacebuilding, H. Coward y G. S. SMITH (eds.), New York, State Uni- 


\section{REFERENCIAS BIBLIOGRÁFICAS}

AA.VV.: With God on their Side Sport in the Service of Religion, London, Routledge, 2002.

Aparicio Aldana, R. K.: «La libertad religiosa y de conciencia en las relaciones de trabajo. Un intento de armonización desde el Derecho español y lo resuelto por el Tribunal Europeo de Derechos Humanos», Revista Latinoamericana de Derecho y Religión, vol. 2, núm. 1 (2016).

BARnetT, L.: «Signes religieux dans la sphère publique et liberté de religion», Ottawa, Bibliothèque du Parlement, 2008, disponible en bttp://publications. gc.ca/collections/Collection-R/LoPBdP/PRB-f/PRBO441-f.pdf.

Briones Martínez, I. M.: El Factor Religioso y las Autonomias, Granada, Comares, 2011.

- El delito de odio por razón de religión y de creencias. La educación en la religión contra el terrorismo de la palabra y de la violencia, Madrid, Thomson Reuters, 2018.

Bouazza Ariño, O.: «Notas de Jurisprudencia del Tribunal Europeo de Derechos Humanos», Revista de Administración Pública, núm. 195 (2014), disponible en bttps://dialnet.unirioja.es/descarga/articulo/4935401.pdf

Cachán Cruz, R., y Fernández Álvarez, O.: «Deporte o Religión: un análisis antropológico del fútbol como fenómeno religioso», Apunts. Educación Física y Deportes, núm. 52 (1998), pp. 10-15.

Cazorla PRieto, L. M.: «El arbitraje deportivo», Revista jurídica de Castilla y León, núm. 29 (2013).

Chapman, R.: Culture Wars: An Encyclopedia of Issues, Viewpoints, and Voices, 2 vols., Armonk, New York, M. E. Sharpe, 2009. ProQuest Ebook Central, bttps://ebookcentral.proquest.com/lib/universidadcomplutense-ebooks/detail. action?docID=501518.

Corona, W.: «The parallel of Modern-Day Sport to Religion: an analysis of how society has transformed sport into a spiritual practice», disponible en https://wakespace.lib.wfu.edu/bitstream/handle/10339/39285/Williams_ wfu_0248M_10569.pdf.

Covo, Y.: «Beyond Individual Discrimination: Why FIFA fails to address discriminatory practices in world football», Texas Review of Entertainment and Sport Law, vol. 20, núm. 133 (2019), pp. 133-203.

Crespo Pérez, J. de D.: «El caso Bosman: sus consecuencias», Revista General Informática de Derecho, núm. 622-623 (1996), pp. 8093-8120.

versity of New York Press, 2004. ProQuest Ebook Central, bttps://ebookcentral.proquest. com/lib/universidadcomplutense-ebooks/detail.action?docID=3408399 (consultado el 4 de enero de 2020). 
Curriert, L. M.: «Religion and employment in Northern Ireland: U.S. Influence on antidiscrimination legislation», Comparative Labor Law Journal, vol. 12, núm. 1 (1990), pp. 73-105.

DíAz SuÁrez, A.: «El deporte, una solución a la multiculturalidad», Revista Iberoamericana de Educación, vol. 50, núm. 2 (2009).

DONALD, A., y HOWARD E.: The right to freedom of religion or belief and its intersection with other rights, paper for ILGA-Europe, 2015, pp. 1-21.

Douglas, M.: Símbolos naturales, Madrid, Alianza, 1970.

E. Dubout, «L'interdiction des discriminations indirectes par la Cour européenne des droits de l'homme: rénovation ou révolution? Epilogue dans l'affaire D. H. et autres c. République tchèque, Cour européenne des droits de l'homme (Grande Chambre), 13 novembre 2007», Revue trimestrielle des droits de l'homme, vol. 75 (2008).

Duru, N. H.: «For Fear of the Fans: An Argument for Holding Sports Teams Accountable for Fans' Post-Match Conduct», Texas Review Entertainment E Sports, vol. 20, núm. 1 (2019), pp. 1-24.

ETHERTON, T.: «Religion, Rule of Law and Discrimination», Ecclesiastical Law Journal, vol. 16 (2014), pp. 265-282.

FreEdLAND, M.; VicKers, L.: «Religious Expression in the Workplace in the United Kingdom», Comparative Labor Law E Policy Journal, vol. 30, núm. 3 (2009), pp. 597-626.

García García, R.; David Docal, G.; Ibarra, E., y Calvo Buezas, T.: Grupos de Odio y Violencias Sociales, Madrid, Rasche, 2012.

García MurCia, J.: «Igualdad y no discriminación en las relaciones laborales», en M. E. Casas Baamonde, F. Durán López y J. Cruz Villalón (coords.), Las transformaciones del Derecho del Trabajo en el marco de la Constitución española. Estudios en Homenaje al Profesor Miguel Rodríguez-Piñero y Bravo-Ferrer, Madrid, La Ley, 2006.

García Murcia, J., y Rodríguez Cardo, I. A.: «Signos religiosos en la indumentaria de trabajo y principio de no discriminación: las primeras aportaciones del Tribunal de Justicia», Diario La Ley, núm. 9012 (2017).

FInkINK, M. W.: recensión a la obra de Menschenbild, «Menschenbild: The conception of the employee as a person in western law», Comparative Labor Law E Policy Journal, vol. 23, núm. 2 (2002), pp. 577-638.

Gardiner, S. et al.: Sports Law, 2011, 4. ' ed., London, Routledge.

GonZAlo ORtega, S.: «Libertad religiosa y contrato de trabajo en la jurisprudencia del Tribunal Europeo de Derechos Humanos», Temas Laborales, núm. 145 (2018), pp. 193-241.

González del Valle, J. M.: Derecho Eclesiástico Español, Oviedo, Universidad de Oviedo, 1997.

— «Restricciones a la libertad religiosa», Sociedad, Derecho y Factor Religioso. Estudios en honor del Profesor Isidoro Martín Sánchez, Granada, Comares, 2017, pp. 283-304. 
Gregory, R. F.: Encountering Religion in the Workplace. The Legal Rights and Responsibilities of Workers and Employers, Ithaca, Cornell University Press, 2011.

Hazel, O.: Anti-discrimination and Human Rights Standards in Europe: Lessons for the European Model», Canadian Labor E Employment Law Journal, vol. 14 (2008).

IDlEman, S. C.: «Religious Freedom and the interscholastic athlete», Marquette Sports Law Review, vol. 12 (2001), pp. 295-345.

KunicKA-MichalskA, B.: «La lucha contra la violencia que se produce en las manifestaciones deportivas», EGUZKILORE: CUADERNO DEL INSTITUTO VASCO DE CRIMINOLOGÍA, NÚM. 18 (2004), pp. 43-58.

LAMMPRON, L.: «Competing visions of an inclusive society: The charter of Quebec values and the workplace», Canadian Labour and Employment Law Journal, vol. 20, núm. 2 (2017), pp. 339-354.

MaLIK, K.: From Fatwa to Jihad: The Rushdie Affair and Its Legacy, London, Atlantic, 2009.

Mantecón SÁnchez, J.: «España: Estado en una sociedad secularizada», Sociedad, Derecho y Factor Religioso. Estudios en honor del Profesor Isidoro Martín Sánchez. Editorial Comares, Madrid, 2017, pp. 339-347.

MARTÍnez TorRón, J.: Derecho angloamericano y Derecho canónico. Las raíces canónicas de la «common law», Madrid, Servicio publicaciones de la Facultad de Derecho-Civitas, 1991.

- «Libertad de expresión amordazada? Libertad de expresión y Libertad de Religión en la jurisprudencia de Estrasburgo», Tensiones entre libertad de expresión y libertad religiosa, Valencia, Tirant lo Blanch, 2014, pp. 83-120.

— «Símbolos religiosos institucionales, neutralidad del Estado y protección de las minorías en Europa», Ius Canonicum, vol. 54 (2014), pp. 107-144.

McCrea, R.: «Religion in the Workplace: Eweida and Others v. United Kingdom», Modern Law Review, vol. 77, núm. 2 (2014), pp. 277-291.

Meseguer Velasco, B., y Rodrigo Lara, S.: «La diversidad religiosa en la escuela: orientaciones jurídicas», Documentos del observatorio del pluralismo religioso en España, núm. 7 (2018), disponible en https://www.pluralismoyconvivencia. es/wp-content/uploads/2018/12/Doc.Obs_.7-Diversidad-Religiosa-en-la-escuela. $p d f$ (consultado el 3 de enero de 2020).

Minteguía ArRegui, I.: «Diversidad cultural y deporte profesional», en M. ${ }^{a}$ A. CASTRO Jover (dir.), Interculturalidad y Derecho, Cizur Menor, Aranzadi, 2013, pp. 182-191.

Obare, R. S.: «Can Sports Exist Without Religion?», disponible en bttps://www. sheffield.ac.uk/polopoly_fs/1.71451!/file/obare.pdf.

Ollero, A.: «Religious Symbols in Public Spaces: Ethical and Legal Arguments», en I. Olza, Ó. Loureda y M. Casado (eds.), Language Use in the Public Sphere. Methodological Perspectives and Empirical Applications, colección «Linguis- 
tic Insights: Studies in Language and Communication», núm. 170, Bern, Peter Lang, 2013, pp. 505-522.

Potz, R.: «The Pluri-Religious Challenge of a Secular State», Religion and Secularism in the European Union. State of Affairs and Current Debates, Brussels, Peter Lang, 2017.

Redman, B. J.: «Sabbatarian Accomodation in the Supreme Court», Journal of Church E State, vol. 3, núm. 3 (1991), pp. 495-524.

Richardson, J. T.: «Managing Religion and the Judicialization of Religious Freedom», Journal for the Scientific Study of Religion, vol. 54, núm. 1 (2015), pp. 1-19.

Rodríguez Piñero y Bravo Ferrer, M.: «Derechos fundamentales del trabajador, poderes empresariales y contrato de trabajo», en A.A.V.V., El trabajo y la Constitución. Estudios en bomenaje a Alonso Olea, Madrid, Ministerio de Trabajo y Asuntos Sociales, 2003.

Rosell Granados, J.: La no discriminación por motivos religiosos en España, Madrid, Ministerio de Trabajo y Asuntos Sociales, 2008.

SEIFERT, A.: «Religious expression in the workplace: The case of the federal republic of Germany», Comparative Labor Law E Policy Journal, vol. 30, núm. 3 (2009), pp. 529-568.

SheEHAN, M.: «Managing Legal Conflicts When Business Dress Codes and Religious Dress Codes Clash», International Labor Rights Case Law, vol. 2 (2016), pp. 86-90.

SuÁrez González, O.: «La Inmunidad Olímpica. La violación de derechos de los deportistas y la propuesta para la creación de un mecanismo jurídico de protección», disponible en bttp://hdl.handle.net/10803/586254.

Trothen, T. J.: «Sport, Spirituality, and Religion: New Intersections», Religión vol. 10, núm. 10 (2019), pp. 545 y ss., disponible en bttps://doi.org/10.3390/ rel10100545.

VAlEnCia CANDAlija, R.: «¿Está la religión en fuera de juego?: reflexiones relativas a la presencia de símbolos religiosos en el fútbol», Anuario de Derecho Eclesiástico del Estado, núm. 34 (2018), pp. 25-261.

Vickers, L.: Religious Freedom, Religious Discrimination and the Workplace, London, Hart Publishing 2008.

Wintemute, R.: «Accommodating Religious Beliefs: Harm, Clothing or Symbols, and Refusals to Serve Others», Modern Law Review, vol. 77, núm. 2 (2014), pp. 223-253.

\section{Resoluciones y documentos}

«Working session 6: Fundamental freedoms II, including freedom of thought, conscience, religion, or belief», disponible en bttps://www.osce.org/ odibr/343771? download=true (consultado el 15 de marzo de 2020).

Bouchard, G., y TAYlor, C., Construir el futuro. El tiempo de la reconciliación, Gipuzkoa, Ikuspegi-Observatorio Vasco de Inmigración, disponible en 
bttps://www.ikuspegi.eus/documentos/investigacion/es/txostena5_cas.pdf (consultado el 10 de octubre de 2019).

«Año internacional del deporte y la educación física», carta de fecha 28 de mayo de 2003 dirigida al Secretario General por el Representante Permanente de Túnez ante las Naciones Unidas, disponible en https://undocs.org/es/A/58/142 (consultado el 20 de octubre de 2019).

«El deporte como medio de promover la educación, la salud, el desarrollo y la paz», Resolución aprobada por la Asamblea General el 27 de octubre de 2004, disponible en bttps://undocs.org/es/A/RES/59/10.

«El deporte como medio de promover la educación, la salud, el desarrollo y la paz», Resolución aprobada por la Asamblea General el 3 de noviembre de 2006, disponible en bttps://undocs.org/es/A/RES/61/10.

«Creación, mediante el deporte, de un mundo mejor en el que reine la paz», carta de fecha 5 de octubre de 1993 dirigida al Secretario General por el Representante Permanente de Egipto ante las Naciones Unidas, disponible en bttps:// undocs.org/es/A/48/237.

Conferencia Internacional de Ministros y Altos Funcionarios encargados de la Educación Física y el Deporte, 6 ${ }^{\text {th }}$, Kazan, Russian Federation, 2017. Plan de acción de Kazán, disponible en https://unesdoc.unesco.org/ark:/48223/ pf0000252725_spa.

Resolución del Parlamento Europeo, de 2 de febrero de 2017, sobre un enfoque integrado de la política del deporte: buena gobernanza, accesibilidad e integridad [2016/2143(INI)], disponible en bttps://www.europarl.europa.eu/doceo/ document/TA-8-2017-0012_ES.html.

\section{Legislación y jurisprudencia}

Ley 10/1990, de 15 de octubre, del Deporte, disponible en https://www.boe.es/ eli/es/l/1990/10/15/10/con.

Real Decreto 203/2010, de 26 de febrero, por el que se aprueba el Reglamento de prevención de la violencia, el racismo, la xenofobia y la intolerancia en el deporte, disponible en https://www.boe.es/buscar/doc.php?id=BOE-A-2010-3904.

Proposición de Ley por la que se modifica la Ley 19/2007, de 11 de julio, contra la violencia, el racismo, la xenofobia y la intolerancia en el deporte, para erradicar la homofobia, la bifobia y la transfobia (622/000007), disponible en $\mathrm{bttp} / / \mathrm{www}$. senado.es/legis13/publicaciones/pdf/senado/bocg/BOCG_D_13_20_392.PDF.

Real Decreto 610/2019, de 25 de octubre, por el que se regula la concesión directa de una subvención al Comité Paralímpico Español para la realización de actuaciones de interés público, disponible en https://www.boe.es/diario_boe/ txt.php? $i d=B O E-A-2019-15406$.

Directiva 2000/78/CE, del Consejo, de 27 de noviembre de 2000, relativa al establecimiento de un marco general para la igualdad de trato en 
el empleo y la ocupación, disponible en https://www.boe.es/buscar/doc. php? id $=$ DOUE-L-2000-82357.

Real Decreto Legislativo 2/2015, de 23 de octubre, por el que se aprueba el texto refundido de la Ley del Estatuto de los Trabajadores, BOE, núm. 255, de 24 de octubre de 2015, disponible en https://www.boe.es/eli/es/ rdlg/2015/10/23/2/con.

Ley Orgánica 3/2007, de 22 de marzo, para la igualdad efectiva de mujeres y hombres, disponible en https://www.boe.es/buscar/act. $p h p$ ? id =BOE- $A-2007-6115 \varepsilon p=20190307 \varepsilon t n=3$.

Manual de legislación europea contra la discriminación, disponible en bttps://fra. europa.eu/sites/default/files/fra_uploads/fra-2018-handbook-non-discrimination -law-2018_es.pdf.

Decisión Marco 2008/913/JAI del Consejo, de 28 de noviembre de 2008, relativa a la lucha contra determinadas formas y manifestaciones de racismo y xenofobia mediante el Derecho penal, DO L, núm. 328, 6 de diciembre de 2008, disponible en bttps://www.boe.es/buscar/doc.php?id=DOUE-L-2008-82444.

Ley 51/2003, de 2 de diciembre, de igualdad de oportunidades, no discriminación y accesibilidad universal de las personas con discapacidad, $B O E$, núm. 289, de 3 de diciembre de 2003, disponible en https://www.boe.es/eli/ es/l/2003/12/02/51/con (consultado el 17 de julio de 2020).

Ley 62/2003, de 30 de diciembre, de medidas fiscales, administrativas y del orden social, BOE, núm. 313, de 31 de diciembre de 2003, disponible en bttps:// www.boe.es/eli/es/l/2003/12/30/62/con (consultado el 17 de julio de 2020).

Directiva 2000/78/CE del Consejo, 27 de noviembre de 2000, relativa al establecimiento de un marco general para la igualdad de trato en el empleo y la ocupación, disponible en https://eur-lex.europa.eu/legal-content/ES/ TXT/?uri=LEGISSUM\%3Ac10823.

Real Decreto-ley 6/2019, de 1 de marzo, de medidas urgentes para garantía de la igualdad de trato y de oportunidades entre mujeres y hombres en el empleo y la ocupación, disponible en https://www.boe.es/boe/dias/2019/03/07/pdfs/ BOE-A-2019-3244.pdf.

Recomendación general núm. 25, sobre el párrafo 1 del art. 4 de la Convención sobre la eliminación de todas las formas de discriminación contra la mujer, referente a medidas especiales de carácter temporal, disponible en https://www.unwomen. org/es/how-we-work/gender-parity-in-the-united-nations/strategies-and-tools.

Recomendación general núm. 32, Significado y alcance de las medidas especiales en la Convención Internacional sobre la Eliminación de todas las Formas de Discriminación Racial. CERD/C/GC/32, disponible en bttps://www.acnur.org/fileadmin/Documentos/BDL/2012/8464.pdf (consultado el 8 de agosto de 2020).

Sentencia TJUE, de 15 de diciembre de 1995, asunto C-415/93, disponible en http://curia.europa.eu/juris/showPdf.jsf?docid=99445\&doclang=ES.

Sentencia TJUE, de 8 de mayo de 2003, disponible en bttps://eur-lex.europa.eul legal-content/ES/TXT/PDF/?uri=CELEX:62000CJ0438\&from=EN. 
European Court of Human Rights. Research Division. Overview of the Court's case - law on freedom of religion, Documento emitido por el Consejo de Europa. Ver lo relativo al empleo, pp. 23-52, disponible en https://www.echr.coe. int/Documents/Research_report_religion_ENG.pdf.

Chaplin v. Royal Devon [2010] ET 1702886/2009 (24 de mayo de 2010) at [20]; Eweida [2010] EWCA Civ 80 at [94], disponible en https://lawandreligionuk. com/2013/01/17/chaplin-eweida-ladele-and-mcfarlane-the-judgment/.

Sentencia del TJUE, caso Asma Bougnaoui y Association de défense des droits de l'bomme (ADDH) contra Micropole SA, de 14 de marzo de 2017 (C-188/15), Revista General de Derecho Canónico y Derecho Eclesiástico del Estado, núm. 44 (2017).

Tribunal Supremo, Sala de lo Social, Sentencia de 18 de julio de 2011, Recurso de Casación núm. 133/2010, Ponente Excmo. Sr. José Manuel López García de la Serrana, disponible en https://supremo.vlex.es/vid/322008279.

STEDH, Weller contra Hungría (núm. 44399/05), 31 de marzo de 2009, disponible en https://www.echr.coe.int/Documents/Handbook_asylum_SPA.pdf

STEDH, D. H. y otros contra la República Checa [GC] (núm. 57325/00), 13 de noviembre de 2007, disponible en https://www.escr-net.org/es/caselaw/2017/ case-dh-and-others-v-czech-republic-app-nocaso-dh-y-otros-c-republica-checa-petic-nro

Abmad v. UK (1982) 4 EHRR 126, disponible en bttp://budoc.echr.coe.int/ eng-press? $i=003-3191940-3556501$.

Stedman v. United Kingdom (1997) 23 EHRR CD 168, disponible en bttp://budoc. echr.coe.int/fre? $i=001-3620$.

(1996), 8 Eur. Comm'n H.R.D.R. 68, disponible en bttp://budoc.echr.coe.int/ fre? $i=001-3379$.

UKET 3400174/2013, 13 de septiembre de 2015. Ver su comentario: Elimination of Discrimination at the Workplace, en International Labor Rights Case Law International BRILL 2 (2016).

STEDH, Burden contra el Reino Unido [GC] (núm. 13378/05), 29 de abril de 2008, disponible en https://www.legaltoday.com/bistorico/jurisprudencialsentencia-num-tribunal-europeo-de-derechos-bumanos-estrasburgo-seccion -2-23-02-2016-2016-04-14/

Bilka-Kaufhaus GmbH contra Weber Von Hartz, TJUE, Bilka-Kaufhaus GmbH contra Weber Von Hartz, Asunto 170/84 [1986] Rec. 1607, 13 de mayo de 1986, disponible en https://eur-lex.europa.eu/legal-content/ES/ TXT/? uri=CELEX\%3A61984CJ0170.

TJUE, Johnston contra Chief Constable of the Royal Ulster Constabulary, Asunto 222/84 [1986] Rec. 1651, 15 de mayo de 1986, disponible en https:/leur-lex. europa.eu/legal-content/ES/ALL/?uri=CELEX:61984CJ0222.

Judgment of the Court of 21 May 1985. 61983J0248. Commission of the European Communities v. Federal Republic of Germany, Equal treatment for men and women, Case 248/83, disponible en https://eur-lex.europa.eu/legal-content/ EN/TXT/HTML/?isOldUri=true\&uri=CELEX:61983CJ0248. 
STEDH, Thlimmenos contra Grecia [GC] (núm. 34369/97), 6 de abril de 2000, disponible en https://co-guide.org/es/jurisprudence/thlimmenos-vs-grecia-solicitud-n\% C2 por 100BA-3436997.

STEDH, Pretty contra el Reino Unido (núm. 2346/02), 29 de abril de 2002, disponible en bttps://www.law.utoronto.ca/utfl_file/count/documents/reprobealth/ echr_uk_2002_pretty_espanol.pdf.

Supreme Court of the United States: Equal Employment Opportunity Commission v. Abercrombie \& Fitch Stores, Inc., núm. 14-86, junio de 2015, International Labor Rights Case Law, vol. 2 (2016), disponible en https://www.law.cornell. edu/supremecourt/text/14-86.

Daniels v. City of Arlington, 246 F. $3^{\mathrm{d}} 500$ ( $5^{\text {th }}$ Cir. 2001), disponible en bttps://casetext.com/case/daniels-v-city-of-arlington-tex.

Wilson v. West Communications, 58 F.3 1337 (8 1 th Cir. 1995), disponible en https://caselaw.findlaw.com/us-8th-circuit/1054976.html.

EEOC v. Kelly Services, Inc., 598 F. $3^{\text {d }} 1022$ ( $8^{\text {th }}$ Cir. 2010), disponible en https:// www.courtlistener.com/opinion/638/eeoc-v-kelly-services-inc/.

U.S. v. New York City Transit Authority, 97 F. $3^{\mathrm{d}} 672$ (2d Cir. 1996), disponible en bttps://casetext.com/case/us-v-new-york-city-transit-authority-3.

EEOC v. Reads, Inc., 759 F. Supp. 1150 (E.D. Pa. 1991)759 F. Supp. 1150 (E.D. Pa. 1991), disponible en https://law.justia.com/cases/federal/district-courts/ FSupp/759/1150/1472997/.

Multani v. Commission scolaire Marguerite-Bourgeoys, 2006 SCC 6, [2006] 1 SCR 256, disponible en https://scc-csc.lexum.com/scc-csc/scc-csc/en/item/15/index.do.

Rv Big M Drug Mart Ltd, [1985] 1 SCR 295, 60 AR 161, disponible en bttps://scccsc.lexum.com/scc-csc/scc-csc/en/item/43/index.do.

TEDH en el asunto S.A.S. c. Francia [GC], núm. 43835/2011, ECHR 2014, disponible en bttps://dialnet.unirioja.es/descarga/articulo/4842602.pdf.

Azmi v. Kirklees Metropolitan Council [2007] ICR 1154, disponible en bttps:// uk.practicallaw. thomsonreuters.com/7-375-8114?transition Type=DefaultEconte $x t$ Data $=($ sc.Default $)$ Ef frstPage $=$ true. 